\title{
Occasional Papers/
}

Reprints Series

in Contemporary

Asian Studies

NUMBER $5-1982(50)$

CONSTITUTIONAL REVOLUTION IN

JAPANESE LAW, SOCIETY AND POLITICS

Lawrence W. Beer

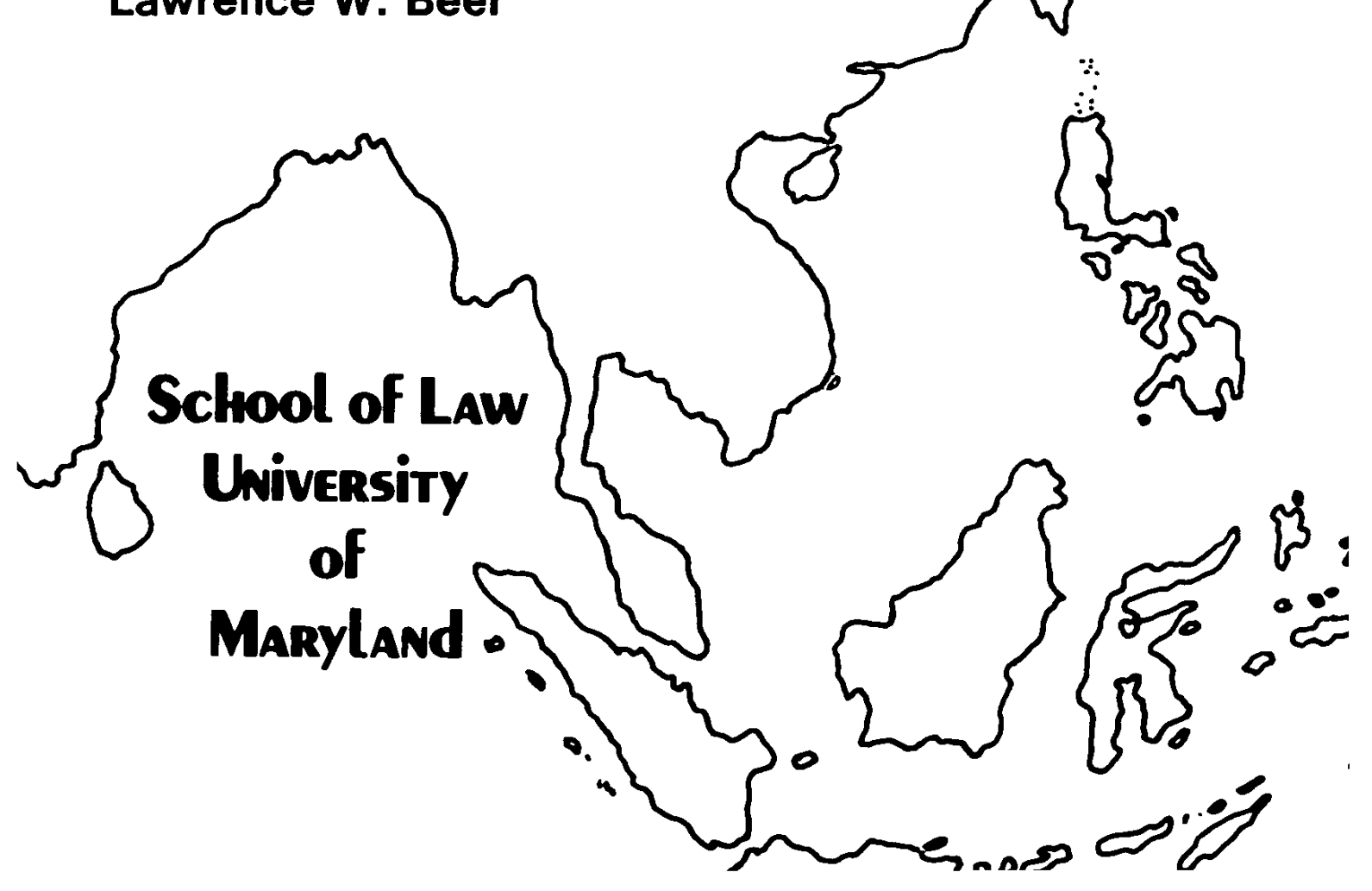




\title{
Occasional Papers/Reprint Series in Contemporary Asian Studies
}

\author{
General Editor: Hungdah Chiu \\ Executive Editor: David Salem \\ Managing Editor: Shirley Lay \\ Editorial Advisory Board \\ Prófessor Robert A. Scalapino, University of California \\ at Berkeley \\ Professor Martin Wilbur, Columbia University \\ Professor Gaston J. Sigur, George Washington University \\ Professor Shao-chuan Leng, University of Virginia \\ Professor Lawrence W. Beer, University of Colorado \\ Professor James Hsiung, New York University \\ Dr. Robert Heuser, Max-Planck-Institute for Comparative Public \\ Law and International Law at Heidelberg \\ Dr. Lih-wu Han, Political Science Association of the \\ Republic of China \\ Professor K. P. Misra, Jawaharlal Nehru University, India \\ Professor J. S. Prybyla, The Pennsylvania State University \\ Professor Toshio Sawada, Sophia University, Japan \\ Published with the cooperation of the Maryland International Law Society \\ All contributions (in English only) and communications should be sent to \\ Professor Hungdah Chiu, University of Maryland School of Law, \\ 500 West Baltimore Street, Baltimore, Maryland 21201 USA. \\ All publications in this series reflect only the views of the authors. \\ While the editor accepts responsibility for the selection of materials to be published, \\ the individual author is responsible for statements of facts and expressions of opinion \\ contained therein. \\ Subscription is US $\$ 10.00$ for 8 issues (regardless of the price of individual issues) in \\ the United States and Canada and $\$ 12.00$ for overseas. Check should be addressed to \\ OPRSCAS and sent to Professor Hungdah Chiu.
}

Price for single copy of this issue: US $\$ 2.00$

(C) 1982 by Occasional Papers/Reprints Series in Contemporary Asian Studies, Inc.

ISSN 0730-0107

ISBN 0-942182-49-9 


\title{
CONSTITUTIONAL REVOLUTION IN JAPANESE LAW, SOCIETY AND POLITICS*
}

\author{
Lawrence W. Beer**
}

TABLE OF CONTENTS

The Two Modern Constitutional Revolutions............. [33]

The Revision Controversy ........................... [37]

Japan's Constitutional Theory ................... 12 [44]

Constitutional Culture and Law ................... 14 [46]

The Law of Demonstrations .................... 17 [49]

Some Aspects of Freedom for the

Mass Media ................................. 20 [52]

Conclusion: Some Problems and Prospects ........... 30 [62]

* Originally published in Modern Asian Studies, Vol. 16 (1982), No. 1, pp. 33-67 and copyrighted by Cambridge University Press, reprinted here with the permission of the author. Original page numbers of the paper appear in brackets.

** Fred Morgan Kirby Professorship of Civil Rights, Lafayette College, Easton, PA 18042. 



\title{
Constitutional Revolution in Japanese Law, Society and Politics
}

\author{
LAWRENCE W. BEER \\ University of Colorado at Boulder, U.S.A.
}

Modern Japan has experienced two constitutional revolutions, one from the latter half of the nineteenth century until I 945 , and the other since I945. By 'constitutional revolution' is meant a long process in which a fundamental shift takes place in constitutional values diffused throughout society by means of law, administrative actions, judicial decisions, and education, both formal and informal.

Previous to these modern constitutional revolutions, neo-Confucianism, already well known and understood in $\mathrm{I} 600$, was adapted to produce what might be called the Tokugawa constitutional revolution. ${ }^{1}$ In contrast to this, the two modern constitutional revolutions were not precipitated by the maturing of internal forces over a long period. They were assimilative reactions to Western legal traditions. As a result, contemporary Japanese law blends traditional elements with European (especially German) civil law and legal theory, and Anglo-American common law traditions.

In this article I offer some data and reflections on (I) prewar and present Japanese constitutionalism and the revision debate; (2) legal culture, embracing the legal system and values, as related to such issues as freedom of expression; and (3) some pending problems in Japanese constitutional law.

\section{The Two Modern Constitutional Revolutions}

Pre-I945 concepts of constitutionalism and law affect legal interpretation and debate today. Many leading judges, prosecutors, legal

${ }^{1}$ David M. Earl, Emperor and Nation in Japan (Seattle: University of Washington Press, 1964); John Fairbank et al., A History of East Asian Civilization-East Asia: The Great Tradition (Boston: Houghton-Mifflin, 1960); and Dan Fenno Henderson, Conciliation and Japanese Law: Tokugawa and Modem, 2 vols (Seattle: University of Washington Press, I968), vol. I. 
scholars and lawyers have had to straddle mentally two constitutional eras, and received much of their formative training and experience under the pre-I945 legal system. The Meiji constitutional revolution (1868-1945) ${ }^{2}$ institutionalized the system against which much of the post-1 945 constitutional system has been a reaction, but also laid the foundation for aspects of the post-1945 revolution.

Study of the law, administrative practice and police developments affecting freedom of expression between I 868 and I 945 suggests that most parts of a thorough system for restraining free speech had fallen into place by 1913 after piecemeal development, and that enforcement of the Peace Preservation Law of 1925 and subsequent related law brought a final touch of unusual sophistication to the pre- 1945 system of control, for which the military were not as responsible as sometimes assumed. ${ }^{3}$ Neither the legal system nor traditional culture seems to have honored individual rights, as rights came to be understood in Japanese law under Western influence.

Rights and freedoms were quite new concepts in Meiji Japan. However, the absence in Japan of a long and coherent tradition of liberalism does not imply that the Meiji constitutional revolution did not vastly expand pre-existing group tendencies to assertion for and against policies in accord with their sense of justice and self-interest. ${ }^{4}$ In general, the maintenance of civil liberties in a country does not depend on explicit emphasis in law or society upon rights and freedoms, as understood in the law and intellectual traditions of the West, but on: ( $\mathrm{I}$ ) a mixture of institutionalized values which taken together favor liberty; (2) the existence of competitive, as opposed to authoritarian, politics; (3) actual expression of agreement or dissent on substantive issues along with the possibility of dissent with impunity; (4) such a balance of social

2 Dan Fenno Henderson, 'Law and Political Modernization in Japan,' in Robert E. Ward (ed.), Political Development in Modern Japan (Princeton: University Press, 1968); and Hideo Tanaka (ed.), assisted by Malcolm D. H. Smith, The Japanese Legal System (Toyko: University of Tokyo Press, I 976), pp. 194-253. For a concise historical analysis of rights in the West, see Richard P. Claude, 'The Classical Model of Human Rights Development,' in Richard P. Claude (ed.), Comparative Human Rights (Baltimore: Johns Hopkins University Press, 1976), pp. 6-50.

${ }^{3}$ Yasuhiro Okudaira, Political Censorship in Japan, 1931-1945 (Philadelphia: University of Pennsylvania Law School Library, I962), esp. pp. I-50.

${ }^{4}$ Probably the most valuable compilation of detailed studies and official trial records of group political actions in Japan from the 1860 s till the Pacific War is Seiji saiban shiroku, 5 vols (Daiichi Hōki, I 969-70), edited by Daiichi Hōki publishing co. An additional five volumes on recent decades were published in 1980 . These studies amply illustrate preferences for group, as opposed to individual, assertiveness, and for other traditional values (referred to later in this paper) which antedated but are not integrated with Western legal ideas of justice. 
and political forces that those favoring rights outweigh those opposed. ${ }^{5}$ The sociological interplay of such factors in Japan from the 1860 s through the 1930s resulted in a growing awareness of individual legal rights, as understood today in Japanese and Western law, among many scholars, officials and other citizens at the same time that a modern system of political repression was being refined and increasingly enforced in service to the Emperor.

The constitutional system of Japan today, reflecting a quite different interplay of factors, stresses enforcement of individual rights. The present widespread acceptance of the constitution in Japan rests in part on a continuing reaction against a prewar system that failed in the mind-numbing defeat of the Second World War. It does not seem probable that Japan would soon have become a constitutional democracy without the shock of losing the Pacific War and without massive Occupation support for Japan's liberal forces. ${ }^{6}$ Modern political systems which are systematically authoritarian, whether left or right in orientation and however inefficient in light of abstract goals, appear much simpler to maintain as regimes than constitutional democracies. Japan's authoritarian apparatus, by comparative standards, was efficient in its methods of political control during the militarist period, and not likely to evolve along more liberal lines.

The widespread, deep, and genuine loyalty to the emperor-nation of that earlier era is not much discussed in public today, and is perhaps remembered more often with embarrassment than with pride. The rejection now of significant military power under the pacifist provisions of Article $9^{7}$ and the denial of power to the Emperor under Chapter $I^{8}$ of

${ }^{5}$ William Spinrad, Civil Liberties (Chicago: Quadrangle Books, 1970), pp. 5-26, 292-306. See Okudaira, Political Censorship in Japan; Richard Mitchell, Thought Control in Prewar Japan (Ithaca: Cornell University Press, I976); and Patricia Steinhoff, 'Legal Control of Ideology in Prewar Japan,' unpublished paper, International Congress of Orientalists, Canberra, Australia, 1970.

${ }^{6}$ See Legal Reforms in Japan during the Allied Occupation, special reprint volume, Washington Law Review, I 977.

7 'Article 9. Aspiring sincerely to an international peace based on justice and order, the Japanese people forever renounce war as a sovereign right of the nation and the threat or use of force as a means of settling international disputes.

' 2 . In order to accomplish the aim of the preceding paragraph, land, sea, and air forces, as well as other war potential, will never be maintained. The right of belligerency of the state will not be recognized.' The Constitution of Japan, in I toh and Beer, The Constitutional Case Law of Japan (Seattle: University of Washington Press, 1978), p. $25^{8}$. According to Chalmers Johnson, the Japanese senryoku, the usual Japanese translation of war potential in paragraph 2 of Article 9, is a mistranslation, as senryoku means fighting power or strength, something more limited than war potential. The constitution does not, therefore, limit senbi or gunbi which have the wider meaning implied in war 
the constitution seem intimately linked in the Japanese mind to the utter national failure resulting from total and militant loyalty to the Emperor. Just as prewar children were programmatically indoctrinated in kokutai ideology, so postwar children have been conditioned systematically to believe in freedom ever since the first student was required to memorize the new constitution during the Occupation $\left(1945^{-52}\right) .{ }^{9}$ The shock of those who had believed unquestioningly in the invincibility of the nation under the Emperor, although profound, is as difficult to convey to today's youth as it is to make real to America's affluent youth the depression years.

Closely associated in the collective memory of the 'militarist period' is the severe, even irrational, limitation of the freedom of thought, the freedom of expression, and other individual rights. The radical postwar rejection by the overwhelming majority of the prewar military-bureaucratic system, which is seen as having misused the imperial institution for its own ends, explains in part why efforts to alter notably the status of Japan's Self-Defense Forces, or the Emperor, or individual rights are perceived by many liberal and leftist Japanese as an attempt to rip apart the entire fair fabric of the 1947 constitution, and not simply as an attempt to modify one of its elements. Whether or not this perception represents a persuasive assessment of relationships, the three parts are commonly seen as crucial and inseparable; no other components of the new constitutional structure arouse such noteworthy emotion. More power to the Emperor would mean, it is thought, more power to the military which would mean expanded police powers and less democratic freedom; and conversely, strict limitation of imperial and military functions in government is necessary to assure the maintenance and development of constitutional rights. In sum, the term 'Peace Constitution' is used in Japan as a reference to the anti-militarist provisions of the constitution, its guarantee of individual rights, and imperial powerlessness.

potential, and which, owing to Japan's industrial potential, is considerable. C. Johnson, 'Omote (Explicit) and Ura (Implicit): Translating Japanese Political Terms,' Journal of Japanese Studies, Vol. 6, No. I (Winter 1980), p. I 14.

8 'Article 4 . The Emperor shall perform only such acts in matters of state as are provided for in this Constitution and he shall not have powers related to government.' Ibid., p. 257.

9 Lawrence W. Beer, 'Education, Politics and Freedom of Expression in Japan: the Ienaga Textbook Review Cases,' Law in Japan: An Annual, Vol. 8 (1975), 67-9o; Ronald Suleski, 'A New Generation of Japanese Intellectuals,' Japan Foundation Newsletter, 6, No. 4 (October-November, 1978), Pp. 10-12. 


\section{The Revision Controversy}

The Constitution of Japan has not been amended even once, as the constitutional revolution of postwar Japan has continued to take root. As it has been applied, it seems sufficiently flexible to remove any pressing need for amendment. The Meiji Constitution was never amended, unless the establishment of the present constitution is viewed technically as a constitutional amendment. ${ }^{10}$ The aspects of perception described above seem a critical factor underlying the seriousness of academic, legal and political debate on questions of constitutional interpretation and revision over the past thirty years. A litmus test applied to scholars and politicians, as well as to laws and judicial decisions on many issues is how they relate to the tripartite revision issue. So thoroughly integrated into political and legal rhetoric is this constitutional sensitivity that court cases concerning a wide range of subjects-for example, history textbook certification, academic freedom, demonstrations, the rating of teachers, and the Japan-United States Security Treaty - have evoked references to all aspects of the tripartite image of Emperor, military, and individual rights.

Once the Allied Occupation ended in 1952, the revision controversy gathered momentum and reached a peak during the mid- and late-r 950s following the formation of the Liberal-Democratic Party (LDP) and the Japan Socialist Party (JSP) by coalitions of smaller parties. Some powerful LDP leaders wanted revision precisely to strengthen the positions of the Emperor and the military and to limit individual rights; but this does not mean a widespread desire existed in the LDP for a return to the political system of the wartime period from the Manchurian Incident (193 I) till late 1945, during which period bureaucrats and militarists decisively replaced elected party politicians as top leaders of the government. ${ }^{11}$

\footnotetext{
${ }^{10}$ The Constitution of Japan was promulgated on November 3,1946 and went into effect on May 3, 1947. The amendment provision in The Constitution of the Empire of Japan was as follows: 'Article 73 . When it has become necessary in future to amend the provisions of the present Constitution, a project to the effect shall be submitted to the Imperial Diet by Imperial Order.

'2. In the above case, neither House can open the debate, unless not less than two-thirds of the whole number of Members are present, and no amendment can be passed, unless a majority of not less than two-thirds of the Members present is obtained.' Tanaka, Japanese Legal System, p. 23.

${ }^{11}$ On the history of the revision controversy, see Haruhiro Fukui, 'The Liberal Democratic Party and Constitutional Revision,' in David Sissons (ed.), Papers on Modern Japan (Canberra: Australian University Press, 1968), and 'Twenty Years of Revi-
} 
At least six factors seem to have virtually eliminated the probability of wholesale constitutional revision in Japan's near future, assuming no severe economic upheaval:

(I) The Security Treaty Crisis of 1960 seems to have been more of a community rite affirming consensual democracy than an anti-treaty or revolutionary struggle. ${ }^{12}$ It was the largest mass movement in Japanese history, ${ }^{13}$ and it may well have suggested to LDP leaders such as Prime Minister Ikeda Hayato that an effort at major constitutional change, whether needed or not, would awaken organized opposition on a much grander scale than that of 1960 .

(2) The Sunagawa Decision of the Supreme Court ${ }^{14}$ spoke of Japan's natural right of self-defense and held Japan's cooperation and security treaty with the United States to be constitutional under Article 9. This decision may have reduced the revisionists' sense of urgency about revision for the sake of Japan's military security. The present Security Treaty of 1960 was similarly upheld by the Supreme Court on April 2, I969. ${ }^{15}$ Two other aspects of Japan's politics tend to support Article 9's anti-militarism and Article 66-2, a constitutional requirement that 'the Prime Minister and other Ministers of State must be civilians.' First, over 80 percent of the Japanese people support Article 9 and the Security Treaty; 57 percent favor maintaining the Self-Defense Forces at present levels, while only 19 percent support an increase in military sionism,' in Dan Fenno Henderson (ed.), The Constitution of Japan: Its First Twenty rears (Seattle: University of Washington Press, 1969), pp. 41-70; and Reinhard Neumann, The Inaba Affair, Constitution Day and Constitutional Revision,' Law in Japan: An Annual, Vol. 9 (1976), pp. 129-43.

12 Max Gluckman's distinction between 'rituals of rebellion' and 'revolution' may apply to the 1960 Security Treaty Crisis and to some aspects of the University Crisis of 1969. Revolution seeks to overthrow the whole existing order, while ritual rebellion, which may be a luxury limited to societies like Japan with a stable established order, reaffirm the system in venting tensions between leaders and led and between viewpoints. In this connection, see Max Gluckman, Custom and Confict in Africa and Politics, Law, and Ritual in Tribal Society; and Takeo Doi (John Bester, trans.), Anatomy of Dependence (Tokyo: Kodansha International, 1973).

${ }^{13}$ On the Security Treaty Crisis, see George R. Packard III, Protest in Tokyo: The Security Treaty Crisis of 1960 (Princeton: Princeton University Press, 1966); Richard Rabinowitz, 'Law and the Social Process in Japan,' The Transactions of the Asiatic Society of Japan, Third Series, Vol. 1o (1 968): 54-7 I; John M. Maki, Government and Politics in Japan (New York: Praeger Publishers, 1962); Robert Scalapino and Junnosuke Masumi, Parties and Politics in Contemporary Japan (Berkeley and Los Angeles: University of California Press, ig62).

14 Japan v. Sakata, 23 Keishū 3225 (Sup. Ct., Grand Bench, December 16, 1959). For a translation, see John M. Maki (ed.), Court and Constitution in Japan (Seattle: University of Washington Press, 1964), pp. 298-361.

is Japan o. Sakane et al., 13 Keishü (No. 5) 685 (Sup. Ct., Grand Bench, April 2, 1969). A translation appears in Itoh and Beer, Constitutional Case Law of Japan, pp. 103-30. 
strength; and very few Japanese exhibit a sense of external military threat. ${ }^{16}$ Most feel there are greater internal than external threats to the system, and even internal threats are minimal. Second, Article 9 has operated in such a way that the military has been removed from the political drama, and, barring an unforeseeable crisis, this has negated the possibility of a military coup d'etat in Japan. If Japan had a conventional constitution, without Article 9, a strong military, whatever its political alignments, would have at its disposal the instruments of coercion which, Japanese history suggests, it would not be reticent to use politically.

(3) The issuance in 1964 , under the leadership of Professor Takayanagi Kenzō, of a non-committal final report by the Commission on the Constitution (1957-64; Kenpō Chōsakai) also discouraged further revision efforts, at least for some time. No recommendations for amendment were made after six years of hearings, study, and debate. ${ }^{17}$ From its inception, many critics viewed the Commission as a revisionist tool; if such was the original intent of the LDP, it was frustrated. Many scholars and politicians refused to participate in or support the Commission's activities. Whether their participation would have added even greater force to the Commission's final refusal to recommend changes is a moot point. In any case, many opponents of the Commission were actively involved in parallel study groups, which included Commission members, during the long debate over every important and technical provision of the Constitution of Japan. In its function, this debate may be viewed as a Japanese-style constitutional convention, with long consultations at home and abroad, and widespread debates in pursuit of national consensus. Japan had had no opportunity for such a 'convention' under the Occupation.

(4) In the late I940s and early 1950s, food, clothing, and other basic needs were the preoccupations of most, leaving a small minority to

${ }^{16}$ See the opinion poll survey reports in Asahi Shinbun, November I, I 978 and January I, 1979 .

${ }^{17}$ Kenzō Takayanagi (John Maki, trans.), 'The Conceptual Background of the Constitutional Revision Debate in the Constitution Investigation Commission,' Law in Japan: An Annual, Vol. I (1967): 1-24; Robert E. Ward, 'The Commission on the Constitution in the Prospects of Constitutional Change in Japan,' Journal of Asian Studies, Vol. 24 ( 1965 ): 40 1-30; John M. Maki, 'The Documents of Japan's Commission on the Constitution,' Journal of Asian Studies, Vol. 24 (1 965): 475-89; and the final report of the Commission on the Constitution, Kenpō Chōsakai Hókokusho (Okurashō Insatsukyoku, 1964). For commentaries, see Horitsu $\mathcal{F i h o ̄}_{4} 19$ (August, I964): 363-74, and furisuto 303 (August, 1964): 1o-26. A study group, Kenpō Mondai Kenkyükai, opposing the Commission on the Constitution, Kenpō Chōsakai Hōkokusho (Ökurashō Insatsukyoku, 1964). Iwanami Shoten, I964). 
debate ideologies and constitutional ideas. The postwar revolution of thought had a slow start. By far the most frequently cited reason in 1979 for Japan's peace since World War II was 'the personally experienced misery of war, ${ }^{18}$ and popular support for the 'peace constitution' is perhaps equally attributable to that experience, at least initially. The fact is that popular assimilation and support for the constitution has grown, and militates strongly against revision. This has been primarily the result of education, accumulating experience of the operation of the constitution, prosperity, the absence of any appealing alternative, the work of the Commission on the Constitution, and the long-term absence of a perceived external military threat.

(5) The LDP lost in the late I96os and I970s the overwhelming parliamentary power necessary to revise the constitution. This, and factional differences within the LDP render revision very unlikely. Inside and outside the political parties, Japan has many power centers, groups organized along relatively non-authoritarian, quasi-familial lines. A few such centers seem dominant-such as the ruling political party, the Ministries (especially the Finance Ministry), the judiciary, mass media combines, and industry federations - with lesser interest groups or domains filling out the system. In general, loyalty to the small face-to-face group is primary, ${ }^{19}$ and it is quite common for such groups or factions to be in competition with, or at best indifferent to, the others. But they can also freely enter into alliances of mutual benefit, usually for limited periods and for particular purposes. This often happens, for example, among factions of the LDP, and this capacity for making and breaking alliances makes the system dynamic and highly organized. But a consensus within the LDP to revise the constitution is certainly not readily foreseeable, and cooperation with other political parties is much more unlikely. The distribution of seats in the Diet remains fairly stable, the LDP's capacity to retain control of the Diet being primarily due to the absence of an alternative appealing to the voters. In July i 980 , even after an atypical LDP landslide victory, the LDP's 286 seats out of 511 in the lower house and 135 of 252 in the upper house ${ }^{20}$ are far

${ }^{18}$ Asahi Shinbun, November I, 1978 and January I, 1979.

${ }^{19}$ Such loyalty is especially emphasized among white collar workers. See Sepp Linhart, Arbeit, Freizeit und Familie in Japan, with a summary in English (Weisbaden: Otto Harrassowitz, 1976), and Thomas Rohlen, For Harmony and Strength, Japanese White-Collar Organization in Anthropological Perspective (Berkeley: University of California Press, 1974).

${ }^{20}$ The distribution of seats in both Houses of the Diet in July 1980 was as below. For perspective, statistics after the prior two lower house elections and the last upper house election are included. The sudden jump in LDP strength in 1980 was attendant to the 


\section{Constitutional Revolution in Japanese LaW}

short of the two-thirds majority required to amend the constitution. ${ }^{21}$

(6) Also militating against constitutional revision is the institutionalization of the Constitution of Japan through law and judicial decisions. The district, high and Supreme Courts of Japan have been much too diverse in their ideological leanings and interpretive methods to allow blanket characterizations of judicial performance since 1947 with respect to constitutional law. But the net cumulative effect of their work in millions of cases, civil, criminal and administrative, has significantly strengthened the roots of rule of law democracy in Japanese soil. ${ }^{22}$ In unexpected death of Prime Minister Ohira Masayoshi on June 12 during the election campaign. Voter turnout on June 22 was the highest since $1960,74.57 \%$, as citizens rallied around the strongest party and, perhaps, honored the deceased by supporting his party, especially candidates of factions allied with Ohira. See Asahi Shinbun, June 23-26, 1980.

\begin{tabular}{lrrrrr} 
& \multicolumn{3}{c}{ House of } & \multicolumn{2}{c}{$\begin{array}{c}\text { House of } \\
\text { Representatives }\end{array}$} \\
& \multicolumn{1}{c}{ Councilors } \\
Party & 1980 & 1979 & 1976 & 1980 & 1977 \\
JSP & 286 & 253 & 254 & 135 & 125 \\
Komeito & 107 & 107 & 118 & 47 & 53 \\
Democratic Socialist Party & 34 & 58 & 56 & 27 & 28 \\
Japan Communist Party & 33 & 36 & 28 & 12 & 11 \\
New Liberal Club & 29 & 41 & 19 & 12 & 16 \\
Shaminren & 12 & 4 & 17 & 2 & 5 \\
Independents & 3 & 2 & 3 & 2 & 3 \\
Vacancies & 7 & 10 & 6 & 14 & 4 \\
& & & 10 & 1 & 2 \\
\hline & 5 & -2 & - & - & - \\
& 511 & 511 & 511 & 252 & 247
\end{tabular}

In the 1970s, independents usually joined with the LDP, thus assuring it a parliamentary majority. The New Liberal Club is a moderate conservative group which split off from the LDP in the mid-1970s, but often votes with it.

${ }^{21}$ The Constitution of Japan, Article 96:

'Amendments to this Constitution shall be initiated by the Diet, through a concurring vote of two-thirds or more of all the members of each House and shall thereupon be submitted to the people for ratification, which shall require the affirmative vote of a majority of all votes cast thereon, at a special referendum or at such election as the Diet shall specify.

'2. Amendments when so ratified shall immediately be promulgated by the Emperor in the name of the people, as an integral part of this Constitution.' Itoh and Beer, Constitutional Case Law of Japan, p. 268.

${ }^{22}$ Lawrence W. Beer, 'Nihon no saibankan,' Jurisuto, no. 70o, September 15, 1979. Annually, Hōsō Jihōo (Hōsōkai) publishes authoritative statistical reports on cases dealt with by the courts, and Höritsu Jiho (Nihon Hyöronsha) carries reviews of both constitutional case law and constitutional studies (kenpogaku). Although the Supreme Court's share in the judicial caseload is only a small fraction of the whole, by the end of 1977 , it had 'taken cognizance of 183,496 cases, out of which 1,045 cases were referred to the Grand Bench [by petty benches], and in 263 cases the Court declared a law, order, regulation or official act unconstitutional.' Justice in Japan (Tokyo: Supreme Court of Japan, 1978), p. 19. 
addition, family courts, Civil Liberties Commissioners, and Local Administrative Counselors have also brought the law of the constitution to bear in resolving millions of disputes in a quiet atmosphere. ${ }^{23}$ District courts more often than appellate courts ${ }^{24}$ have stressed civil liberties in their findings; but even the now conservative Supreme Court has notably nurtured procedural rights of the accused ${ }^{25}$ while allowing creeping restraints on the rights of public employees, on and off the job. ${ }^{26}$ (Other examples are discussed later.) The courts are restrained by an insufficiency of judges, dilatory trial proceedings, jurisprudence that is sometimes restrictive, and other factors touched on later. In general, the courts have guarded jealously their tradition since the Meiji period $^{27}$ of judicial independence in deciding individual cases; they have also upheld their institutional prerogatives in dealing with the Diet and administrators.

Legal professionals as well as politicians, ranging from rightists to moderate liberals to democratic socialists to those who view Marxists as rank conservatives, seem cautious about the intentions of their political

${ }^{23}$ Family courts, summary courts, and various modes of lay participation in dispute resolution are briefly described in Justice in Fapan. pp. 14-1 7, 23-6. Concerning the Civil Liberties Bureau and Commissioners, see Lawrence W. Beer and G. G. Weeramantry, 'Human Rights in Japan: Some Protections and Problems,' Universal Human Rights, No. 3, I979, Pp. I-33.

${ }^{24}$ Concerning Japan's court system and judges, see Itoh and Beer, Constitutional Case Law of Japan, pp. 7-2 I, 250-5; and, on barriers to civil litigation, John Owen Haley, 'The Myth of the Reluctant Litigant,' Journal of Japanese Studies, (summer, 1978): 359-9o. In Japanese, Wada Hideo, Saikō saibansho ron (Nihon Hyöronsha, 1970), and Saikó saibansho (Högaku seminah-Nihon Hyöronsha, r977).

${ }^{25}$ For example, Abe v. Japan, 20 Keishü (No. 6) 537 (Sup. Ct., Second Petty Bench, July I, I 966), translated in Itoh and Beer, Constitutional Case Law of Japan, p. 167-8.

${ }^{26}$ See, for example, Japan v. Ozawa, 28 Keishü (No. 9) 393 (Supreme Court, Grand Bench, November 6, I974); for comments, see Lawrence W. Beer, 'Recent Developments-Constitutional Law,' Law in Japan: An Annal, Vol. 8 (1975): 205-8, and Nobushige Ukai, 'The Significance of the Reception of American Constitutional Institutions and Ideas in Japan,' in L. W. Beer (ed.), Constitutionalism in Asia (Berkeley and Los Angeles: University of California Press, I979), pp. I 23-6. See generally 'Kenpō no sōten,' Jurisuto zōkan (May, 1978); 'Nihonkoku kenpō,' Jurisuto rinji zōkan, 638 (May, 1977); 'Kenpō zonen no riron to tenbō,' Hōritsu Jihō rinji zōkan (May 1977); Kobayashi Naoki, Kenpō handan no genri, 2 vols (Nihon Hyōronsha, 1978); and Ashibe Nobuyoshi (ed.), Kenpō (Yühikaku, 1978), Vol. 2.

${ }^{27}$ The Otsu Case ( $189 \mathrm{I}$ ) and the Meiji Constitution established judicial independence for the first time in Japan. As Kenzó Takayanagi notes: 'In a sense, the Otsu Incident and its legacy contradict the basic thesis advanced by the Western scholars interviewed by Kaneko: the inclusion in the Constitution of an institution quite foreign to the Japanese scene provided the foundation on which a tradition of judicial independence very quickly emerged.' Takayanagi, supra n. 17. See also Marc Galanter, 'The Displacement of Traditional Law in Modern India,' Journal of Social Issues 24 (1968): $65-91$. 
foes on the revision issue. It is more a debate among elites who would speak on behalf of the citizenry than an issue like economics or education preoccupying the public in general. Many Japanese of otherwise differing views would like the revision controversy to cool down sufficiently to allow a complete rewriting of the Constitution of Japan into appropriate Japanese language without changing the intent of any important provision. That may of course be an impossible dream; but the present translation into Japanese of some parts originally in English is not adequate, and may be an unnecessary reminder of the document's Occupation-period origins. ${ }^{28}$

Some anti-revisionists maintain the LDP policies and the decisions of conservative courts have already revised the constitution in fact, if not formally, in pursuit of a 'reverse course' preference for the prewar order. ${ }^{29}$ Surely, in Japan as in past and present democratic law and politics the world over, one can find much evidence of an abiding preference for anti-democratic policies and judicial decisions at both the official and private levels of society; but the contention that substantive constitutional revision has occurred seems a doubtful political judgment and an oversimplification of the tasks of courts in Japan, unless by 'revision' one really means 'interpretation' which one finds needlessly restrictive. Moreover, the problems in interpreting the Article 9 'no war clause' are unprecedented in world judicial history; they cannot be solved or whisked away by too facile a use of 'political question' doctrine, the view in law that courts have no right to decide certain politically sensitive issues such as those affecting national security. ${ }^{30}$

Japan's power centers criticize each other for wrong-headedness regarding the constitution, and in doing so they manifest the competitive politics essential to the maintenance of liberties. Anti-revisionists retain sensitivity to the repressive past and show awareness that democracy is a vulnerable system of law and government always in some respects in tension with its professed ideals.

${ }^{28}$ See Tanaka (ed.), Japanese Legal System, pp. $642-85$ and works cited therein.

${ }^{29}$ A good presentation of these views is Reinhard Neumann, 'The Inaba Affair, Constitution Day and Constitutional Revision,' supra, n. I I.

${ }^{30}$ Hiroshi Itoh, 'Judicial Decision-making in the Japanese Supreme Court,' Law in Japan: An Annual, vol. 3 (1969): 128-6I; Kisaburo Yokota, 'Political Questions and Judicial Review,' Henderson (ed.), Constitution of Japan, pp. 141-66; Hideo Wada, 'Decisions under Article 9 of the Constitution: The Sunakawa, Eniwa, Naganuma Decisions,' Law in Japan: An Annual 9 ( 1976): 1 1 7-28; 'Recent Developments,' ibid. 153 ; Robert L. Seymour, 'Japan's Self-Defense: The Naganuma Case and Its Implications,' Pacific Affairs, Vol. 47 (1974-75):42 1; and Kenneth M. Tagawa, Justiciability and Judicial Power in Japan, unpublished Ph.D. dissertation, University of Colorado, 1979. 


\section{Japan's Constitutional Theory}

The Constitution of Japan is now the most-authoritative reference point for public values in Japan and is, as Edward Seidensticker has noted, 'among the Sacred Books of the East. ${ }^{31}$ The constitution's theoretical thrust is based on natural law suppositions and on the attribution of intrinsic value to the individual person. So many formal philosophies and ideologies co-exist in Japan's political and intellectual worlds that it is hard to discern any agreed-upon general theory underpinning Japanese constitutional democracy. Among the pillars and struts of Japanese thought are traditional ideas drawn from Buddhism, Confucianism and Shinto, as well as theories related to Christianity and Marxism; but how they relate to each other, if at all, is elusive. ${ }^{32}$ But it is clear that customary law has had a powerful influence. Though generally unwritten, these rules are partially expressed in such documents as company rules. ${ }^{33} \mathrm{~A}$ sophisticated system of rules with effective sanctions governs oyabun-kobun (quasi-parental-filial) group structures ${ }^{34}$ and gives specificity to such motive forces as amae (reciprocal dependency $)^{35}$ and loyalty. Nagao Ryūichi suggests that a better understanding of the enigmatic urge to absolute loyalty - not simply to loyaltymay be a key to understanding the history of Japanese social and political ideas. ${ }^{36}$

Every five years the Institute of Statistical Mathematics in Tokyo conducts comprehensive surveys of Japanese national character. The results indicate that there has been no appreciable modification of a clear Japanese preference for traditional values since 1953. Among the possible approaches to clarifying the principles underpinning or at

${ }^{31}$ Edward Seidensticker, 'Japan After Vietnam,' Commentary (September, 1976): ${ }_{56}$.

${ }^{32}$ Gino Piovesana, Recent Japanese Philosophical Thought (Tokyo: Enderle Bookstore, 1961); Charles A. Moore (ed.), The Japanese Mind (Honolulu: East-West Center Press, I968); Miyazawa Toshiyoshi, Kenpō (Yūhikaku, 1962).

${ }^{33}$ Carl Steenstrup, 'The Company Code,' Asian Law Forum, Vol. I (1 976): $21-5$.

${ }^{34}$ Chie Nakane, Japanese Society (Berkeley and Los Angeles: University of California Press, 1970).

${ }^{33}$ The term 'reciprocal dependency' is taken from Douglas D. Mitchell, Amae: The Expression of Reciprocal Dependency Needs in Japanese Politics and Law (Boulder, Colorado: Westview Press, I976). Mitchell seems to this writer to present Takeo Doi's important views on dependency more systematically and more clearly than Doi himself. See also Takeo Doi, Anatomy of Dependence.

${ }^{36}$ Ryūichi Nagao, in a review of $\mathrm{R}$. Minear, Japanese Tradition and Western Law (Cambridge, Mass.: Harvard University Press, 1970), in Law in Japan: An Annual 5 (1972): 224. A comparative study of the meanings and objects of loyalty would be very helpful as a step toward clarifying the bases of intercultural disagreements. 
variance with the constitution is analysis of the reasons given by voters for their voting preferences. An attitude study of 1,500 Tokyo voters was made in 1978 by a team of Japanese scholars. ${ }^{37}$ Analysis indicated that ideology and party preference were relatively unimportant. The single most important determinant of political choice (the key factor to 29 percent of voters, and a major factor to 53 percent) ${ }^{\mathbf{3 8}}$ was the image of the candidate as expressing and supporting traditional values and what might be termed 'the good Japanese way' of doing things. But a most striking contrast to this preference for traditionalism in the personal style of candidates is found in the analysis of the positive elements in the images which voters entertained of liberalism, capitalism, socialism, and communism: the most likely to succeed were candidates, ideologies, and parties presenting an image of flexibility, modernity, conservatism, and economic egalitarianism somehow combined. For maximum legitimacy, a leader was seen as combining great respect for traditional values and modes of human interaction with concern for constitutional freedoms and economic policies promoting equality. Forty-two percent of the voters studied considered themselves entirely unaffected by political ideologies such as the four above; only I percent consider socialism-communism preferable in general to liberalism-capitalism, but only io percent rate the latter pairing preferable to the former.

Along with the strong support for Article 9 pacifism (not a general philosophy of pacifism) referred to earlier, values such as hierarchy, equality, groupism, freedom and loyalty form at least part of the structure of operative constitutional theory in Japan. Replacing in some measure and without much emotion their earlier loyalty to the Emperor, perhaps the generality of Japanese now share a loyalty to the

${ }^{37}$ Hayashi Chikio et al., Nipponjin no kokuminsei (Shiseido, 1970); and Hayashi Chikio, 'Seiji ishiki no seitai,' Asahi Shinbun, December I6, I978, p. 4. See also the comprehensive survey report in Asahi Shinbun, January I, 1979, Pp. I, 10-I3.

The term 'feudal,' often used pejoratively to criticize traditional aspects of modern Japan, is usually applied to factors such as the family system which predated feudalism by centuries and which made Japanese feudalism different from other feudalisms such as those of Western Europe. See F. Joüon des Longrais, L'est et l'ouest, institutions du Japon et de l'occident comparees (Paris and Tokyo, 1958). This writer does not share a uniformly negative view of Japanese-style 'feudalism' as it functions today.

${ }^{38}$ Hayashi, 'Seiji ishiki no seitai.' Only a small percentage (c. 20\%) of Japanese expressed much trust in politicians in late 1978 compared, for example, to tax officials $(c$. $45 \%$ ), judges, teachers, police, doctors, newspapers, and weather forecasters, among whom the last in the ascending order were the most trusted. Asahi Shinbun, October 22, 1978 and January 1, 1979. My only explanation for the extraordinary trust of forecasters is good-humored Japanese stress on distrust of other categories. Newspapers are trusted institutions, but the results may have been skewed to their advantage by the fact that the newspapers did the polling. 
constitution, not as a formal document, but as a summation of preferred values and guidelines for public action. What the constitution rejects seems as important as the rights it guarantees, but the whole structure rests on a recognition of the equal dignity of each individual. As the late constitutional lawyer Miyazawa Toshiyoshi once expressed it, while contrasting prewar and postwar Japan, 'Every day I enjoy breathing freedom again.'

\section{Constitutional Culture and Law}

The core new element in post-1 $945 \mathrm{~J}$ apanese constitutionalism is legally protected freedom and individual rights, based primarily on the Preamble and Chapter III (Articles 1o to 40) of the constitution. ${ }^{39}$ Japan would very likely be a well-organized (some might say, over-organized) nation under almost any imaginable governmental system; but much was added to order by the present constitutional revolution. The Preamble proclaims that 'sovereign power resides with the people,' and Article I 3 that 'all of the people shall be respected as individuals.' This abstract latter provision has been invoked by the courts as the textual basis for both establishing and limiting certain constitutional rights. The individual person has replaced the Emperor as the highest public value. The Emperor is a 'symbol of the State and of the unity of the people' (Article I); and 'he shall not have powers related to government' (Article 4). This is the first time the powers of the Emperor have ever been legally limited, although historically he seldom, and, since $\mathbf{~} 868$, almost never, actually exercised any political powers. Although continuities do exist which link present and prewar institutions, significant changes have been made in their organization and function. ${ }^{40}$ The Cabinet has no military membership and is collectively responsible to the Diet (Article 66). Constitutional rights, although in fact sometimes subordinate to informal in-group pressures

\footnotetext{
${ }^{39}$ The Constitution of Japan, Article 97 in the 'Supreme Law' chapter of the constitution reads: 'The fundamental human rights by this Constitution guaranteed to the people of Japan are fruits of the age-old struggle of man to be free; they have survived the many exacting tests for durability and are conferred upon this and future generations in trust, to be held for all time inviolate.'

${ }^{40}$ On the severe limitations on the emperor's political role as an individual in the Tokugawa period ( $1600-1868$ ), see Herschel Webb, The Japanese Imperial Institution in the Tokugawa Period (New York: Columbia University Press, 1968), and for the period 1868-1 946, see David A. Titus, Palace and Politics in Prewar Japan (New York: Columbia University Press, 1974), and Modern Asian Studies, 14, 4 (1980), P. 529.
} 
and bureaucratic presumptions, are more freely exercised than in prewar Japan, vastly expanded in scope, usually honored by the police, and justiciable or conciliable in public tribunals. ${ }^{41}$ The mass media serve more adequately than before as a quasi-constitutional Fourth Estate, a power center relatively independent of any political party or Ministry, without which Japanese democracy might crumble. ${ }^{42}$ The Diet is the 'highest organ of State power' (Article 4I) except for the ruling political party, yet subject to judicial review (Article $8 \mathrm{I}$ ) of the constitutionality of its official acts. ${ }^{43}$ The court system, supervised by the Supreme Court, is judicially and administratively independent. Finally, the status of women has improved markedly, in both fact and law. ${ }^{44}$

The Supreme Court and lower courts have the 'power to determine the constitutionality of any law, order, regulation or official act'; 45 but like most court systems, they exercise this power against other branches of government only rarely. They are further restrained by predominantly civil law perceptions of the judicial role in government, a role of democratic deference to the elected parliament. ${ }^{46}$ The technical effect

${ }^{41}$ Regarding the police, who enjoy considerable public respect and trust in Japan, see David H. Bayley, Forces of Order: Police Behavior in Japan and the United States (Berkeley: University of California Press, I976).

Takayanagi Kenzō noted that prewar debates on constitutionality involved political rhetoric, but rarely justiciable rights; supra, n. 32. 'Conciliable rights' is meant to express the prevalent style of dispute resolution, involving a third-party status bearer (informal or official) pursuing compromise and formal harmony. On Japanese right consciousness, see Lawrence W. Beer, 'Freedom of Expression in Japan with Comparative Reference to the United States,' in Claude (ed.), Comparative Human Rights, pp. 101-9; Henderson, Conciliation and Japanese Law.

${ }^{42}$ Discussions in 1978 and 1979 with Itō Masami and Shimizu Hideo. They consider press freedom more critical to democracy in Japan than in most countries.

${ }^{43}$ The Constitution of Japan, 'Article 81. The Supreme Court is the court of last resort with power to determine the constitutionality of any law, order, regulation or official act.' Itoh and Beer, Constitutional Case Law of Japan, p. 266. Lower courts, by judicial decision and Article 76 , also have the power of judicial review.

44 Beer and Weeramantry, 'Human Rights in Japan.'

${ }^{45}$ Article $8 \mathrm{r}$ of the Constitution of Japan. Article 76 is also critical: 'The whole judicial power is vested in a Supreme Court and in such inferior courts as are established by law.

'2. No extraordinary tribunal shall be established, nor shall any organ or agency of the Executive be given final judicial power.

'All judges shall be independent in the exercise of their conscience and shall be bound only by this Constitution and the laws.' I toh and Beer, Constitutional Case Law of Japan, p. 265.

For a study of the prewar administrative court system, to which paragraph 2 of Article 76 is in part a reaction, see Hideo Wada, 'The Administrative Court under the Meiji Constitution,' Law in Japan: An Annual Io ( I 977): I-64.

${ }^{46}$ For comparative perspectives, see Beer (ed.), Constitutionalism in Asia; Ivo Duchacek, 'Constitutions: Adapting to Change,' Power Maps: Comparative Politics of Constitutions (Santa Barbara: ABC Clio Press, 1973), pp. 210-32; Claude, Comparative 
on future law of a judgment of unconstitutionality is still debated, but a 'conclusion in a decision of a superior court shall bind courts below in respect of the case concerned,' and not in general. ${ }^{47}$ For example, if a legal provision is held unconstitutional by the Supreme Court, it is nevertheless possible that the same or other courts may rule differently in other cases on the same issue, and it is possible that the Diet will not pass remedial legislation to remove the offending provision. A judgment of unconstitutionality does not necessarily trigger among lawyers, legal scholars, mass media leaders or politicians the requisite sustained pressure on the Diet to take legislative action to support such a judgment. ${ }^{48}$ If the judicial decision is that an official action is invalid, no court doctrine has resolved the scholarly debate on whether some legal provision enables a court to order an administrative agency to take remedial action. ${ }^{49}$ Article 37 of the constitution guarantees the accused in a criminal case 'the right to a speedy and public trial'; but some controversial cases have languished in the courts for a decade or even two (e.g., the 1952 May Day Incident decisions of the 1970s), and years of delay are commonplace. Widely spaced trial sessions characterize Japan's civil law system, courts have been used at times as political forums, causing additional delays, and judges are generally meticulous in moving slowly towards a decision. These factors may constitute a systematic obstacle to quick justice.

The conviction rate in Japan is extremely high, approaching 99 percent. But in recent years criminological reasons, rather than insufficient evidence have led prosecutors not to prosecute around 40 percent of serious violations of the Criminal Code. A lay Inquest of Prosecution regularly reviews a prosecutor's determinations on whether or not to file charges; these organs recommend a change or indictment or a reinvestigation of the case about ro percent of the time, and such recommendations are accepted by the Chief of the District Public Prosecutor's Office in $3^{\circ}$ percent of the cases. ${ }^{50}$ 'In Japan in 197 I less

Human Rights; David H. Bayley, Public Liberties in the New States (Chicago: Rand McNally \& Co., 1 964). On judicial roles in civil law systems, see John Henry Merryman, The Civil Law Tradition (Stanford: Stanford University Press, 1969); Rudolf B. Schlesinger, 'Common Law and Civil Law: A Historical Comparison,' Comparative Law, 2nd edition (Brooklyn: Foundation Press, 1959), pp. I 79-98.

${ }^{47}$ Article 4, Court Organization Law, Law No. 59 of April 16, 1947. See Itoh and Beer, Constitutional Case Law of Japan, pp. 7-1 1, 25 I-5; Haley, 'Myth of the Reluctant Litigant,' pp. $3^{81-9}$; and on the effect of an unconstitutional judgment, Ukai in Beer, Constitutionalism in Asia.

48 Discussions with judges, Tokyo, 1978-1979.

${ }^{49}$ Haley, 'Myth of the Reluctant Litigant,' pp. $3^{87-90 .}$

${ }^{50}$ Conversation with Matsuo Kōya, specialist in criminal procedure law, 1979. 
than 4 percent of persons convicted were given a jail sentence and almost two-thirds of those were suspended. Over 96 percent of persons convicted of a crime were punished only with a fine,' usually a small fine. Forty-four and seven-tenths percent of the convicted went to prison in the United States that year, and for much longer periods than the Japanese sentenced. Criminal justice in Japan is generally not severe.

Freedom of expression is a sine qua non of any constitutional democracy. A review of the status of freedom of expression will thus be a particularly useful way of conveying reasonably reliable perspectives on the state of Japan's democratic law. Issues to be touched on include the freedom to demonstrate, mass media freedom, privacy, obscenity, and textbook certification.

\section{The Law of Demonstrations}

In any assessment of the strength of freedom, we need to study judicial decisions, which are the backbone of the law on liberty, but especially where values differ from Western ones, we need to understand the society in order to comprehend how law is perceived and how it functions. For example, the Japanese commitment to groupism instead of to individualism has not, and does not, prevent people from resorting to the law to protect their rights and interests. ${ }^{51}$ Nor has it been an obstacle to the people's support for the freedom of expression. ${ }^{52}$ But it has affected the forms that these take.

There is a strong sense of group right rather than individual right in public contexts, analogous to an individualist sense of right in the West. Largely due to this, privately and freely organized demonstrations have been very frequent in postwar Japan. Freedom of association and freedom of assembly have been central aspects of freedom of expression in Japan, and contrast sharply to the prewar suppression of these freedoms. Highly vocal but nonviolent group dissent or advocacy by groups seems more fully accepted public behavior in Japan than in the United States. ${ }^{53}$ Even peaceful marches sometimes arouse considerable

Bayley, Forces of Order, pp. I $4{ }^{\mathrm{I}}-4$. Civil liberties lawyer Ono Masao says police brutality is very rarely a problem; ibid., pp. $16_{5}-6$.

51 Haley, 'Myth of the Reluctant Litigant'; Kahei Rokumoto, 'Problems and Methodology of Study of Civil Disputes,' pt 1, Law in Japan: An Annual 5 (1972): 97-1 14, and pt 2, 6 (1973): I I 1-27.

32 Beer in Claude (ed.), Comparative Human Rights, pp. I OI-9.

${ }^{53}$ On the other hand, individual dissent and post-consensus dissent from the views of one's in-group seem notably limited in Japan. However, pre-consensus debate within 
public ire in the United States, as they did during the civil rights and anti-war movements of the 1960 and 1970 . ${ }^{54}$

A number of agencies and laws regulate demonstrations in Japan, 55 but the most important are the local 'public safety ordinances' (kōan jörei) and 'public safety commissions' (kōan iinkai) of prefectures or cities. ${ }^{56}$ The key constitutional provision on freedom of expression is Article 21:

Freedom of assembly and association as well as speech, press, and all other forms of expression are guaranteed.

2. No censorship shall be maintained, nor shall the secrecy of any means of communication be violated.

Basic Supreme Court doctrine on demonstrations and other 'collective activities' was laid down in the landmark Tokyo Ordinance Decision in $1960,{ }^{57}$ which held that local authorities are obliged under public safety ordinances to grant permits with 'maximum respect for freedom of expression.' Denial of a permit is legitimate only when a collective activity 'will directly endanger the maintenance of the public peace' and thus contravene 'the public welfare' ( $k \bar{o} k y \bar{o}$ no fukushi).

Later judicial decisions have followed and refined Tokyo doctrine. ${ }^{58}$ Although the 'public welfare' was defined early (1950) by the Supreme Court as 'the maintenance of order and respect for the fundamental human rights of the individual, 59 for many years the judicial use of the term has evoked unease and protest from many constitutional lawyers and opposition politicians. 'Public welfare' has reminded them of terms used during the ultra-nationalist period to urge all to forget their own interests and revere the Emperor. ${ }^{60}$

one's group is relatively uninhibited (except by the seniority order of presentation), as is expression of group disagreement with government policies or the opinions of 'outsiders' of whatever kind. See Beer in ibid.

54 See Bayley, Forces of Order, pp. $172-83$.

${ }^{55}$ Freedom of assembly can be regulated under Article 7 of $D \bar{o} r \bar{o} K \bar{o} t s \bar{h} h \bar{o}$ (Law 105 of I960), Article I9 of Densenbyō yobōhō (Law 36 of 1897), Articles 5 and 7, Hakai katsudo bōshihō (Law 240 of 1952), Articles 106 and 107, Keihō, and Article 4 of Ministry of Welfare Order No. I 9 of I 949 (Official Gazette, No. 938); and by public safety ordinances.

${ }^{56}$ On public safety ordinances and their use, see Beer in Claude (ed.), Comparative Human Rights.

57 Japan v. Itō, 14 Keishī I 243 (Sup. Ct., Grand Bench, July 20, 1960). For a translation and the ordinance in question, see Maki (ed.), Court and Constitution in Japan, pp. 84-1 16. For an analysis, see Beer in Claude, Comparative Human Rights, pp. $115^{-18 .}$

58 The Supreme Court can and does on occasion reverse its own precedent. For examples, see Cases 7 and 24 in Itoh and Beer, Constitutional Case Law of Japan.

s9 Japan v. Sugino, 4 Keishü 201 2, 1014 (Sup. Ct., Grand Bench, r950).

60 See Miyazawa Toshiyoshi, Nihonkoku kenpō (Nihon Hyōronsha, 1963), p. 205; and Yamamoto Keiichi, 'Kōkyō no fukushi,' in Tanaka Jirō (ed.), Nihonkoku kenpōo taikei, Vol. 
One of the most significant developments in constitutional law since I 947 may be the decreased use, especially in the lower courts, of abstract formulations of public welfare doctrine, and increased specificity since $1965 .{ }^{61}$ The courts have honed more concrete criteria for determining what the public welfare is in each class of cases. These technical developments are in some cases due more to changes in judicial education, the influence of legal scholars, and accumulated judicial experience under the 1947 constitution than to liberalism. For example, Tokyo doctrine, which was handed down in the aftermath of the 1960 Security Treaty Crisis, deemphasized the place where demonstrations are held. In fact, Tokyo upholds the right of authorities to regulate mass demonstrations 'in any place whatsoever,' contending that debate on such matters as place is 'completely profitless.' But a 1970 Supreme Court decision hinged upon the meaning of 'public place' (kōkyo no basho) in the Hiroshima prefectural ordinance. It was defined by the judges as 'a place which in reality is generally open and can be used and entered freely by unspecified persons. ${ }^{62}$ The ordinance requires a permit only for a demonstration which is to take place in a public place. The accused were public employees who staged a demonstration outside the prefectural capitol building without obtaining a permit. They contended the ordinance did not apply, since the location of the demonstration was not a public place; the judges disagreed, and they lost their case.

Vigorous exercise of the freedom to demonstrate by groups representing local and national interests will likely continue little affected by adverse court decisions. Most public group actions in Japan are orderly and peaceful, and are often attended with colorful pageantry and a festival spirit, a healthy blend of seriousness and play. Convictions for illegal collective activities are usually for physical obstruction or violence which would be held illegal in most or all of the world's other democratic courts; and as noted earlier, Japan's courts are quite lenient in sentencing. On the other hand, the Supreme Court has been criticized when it has overturned acquittals handed down by both a trial court 8 (Yūhikaku, 196r), p. I6. On legal theories in Japan on the public welfare, see Satō Isao, Kenpō Kenkū Nyümon, 3 vols (Nihon Hyōronsha, 1966) 2: 25- I 7.

${ }^{61}$ Ashibe Nobuyoshi et al., 'Kenpō hanrei no zonen,' Jurisuto, special issue (May 3, 1977): 452, 453, and in the same issue commemorating the thirtieth anniversary of Japan's constitution, see Itō Masami, 'Kenpō kaishaku to rieki kōryōron,' p. 20o, on the increased judicial use of an interests-balancing approach. See in general this issue of Jurisuto and Kenpō sanjūnen no riron to tenbō, Höritsu Jihō, rinji zōkan (May, 1977), on Japan's constitutionalism.

${ }^{62}$ See Asahi Shinbun, July 17, 1970 (Sup. Ct., Petty Bench, July 16, 1970); conversations with Justice Irie Toshio, January, I97I. 
and an appellate court; this it did about twenty times between 1974 and 1979 in civil liberties cases. The ever-clearer restriction in the political activities of public employees to voting alone deserves special mention. In the late i 960 s, the Supreme Court recognized that different degrees of restraint are appropriate to a management-level official in a Ministry and a janitor in the public monopoly tobacco corporation. ${ }^{63}$ But between 1973 and 1978, decisions of the Supreme Court affected adversely the political freedom of public employees.

In the famous Sarufutsu Case, ${ }^{64}$ for example, a postal employee was convicted for putting up six political posters on a public bulletin board during his leisure hours. The issues still debated include the proper delineation of limits on the rights of teachers, postal workers, telecommunications workers, and transportation workers to strike or to engage in political activities, and whether administrative discipline (most common), criminal penalties or no punishment should be applied for related violations of the laws governing public employees.

\section{Some Aspects of Freedom for the Mass Media}

Along with group activism, freedom of the press is particularly close to the core of Japanese democracy, because the mass media may represent the only power centers that are effectively organized, separate from the government, linked with important people and groups, especially in Tokyo and Osaka, and whose influences spread throughout the nation.

Japan's print and broadcast media are mammoth in scale, technologically impressive, and socially pervasive. ${ }^{65}$ Daily newspapers with nationwide circulation like the Asahi Shinbun, Mainichi Shinbun, Yomiuri Shinbun, and Nihon Keizai Shinbun print over fifty million copies each day, about twenty percent of which are distributed in Tokyo. The newspapers' political roles are complex, although the major papers do not

${ }^{63}$ See, for example, Japan v. Sakane et al., supra n. 15, and Toyama et al. v. Japan, 20 Keishū (No. 8) go I (Sup. Ct., Grand Bench, October 26, Ig66), in Itoh and Beer, Constitutional Case Law of Japan, pp. 85-13o. See also Rōdo to jinken (Hōgaku seminah-Nihon Hyōronsha, 1978 ).

64 Japan v. Ozawa, 28 Keishü (No. 9) 393 (Sup. Ct., Grand Bench, November 6, 1974). For comment, see Ukai in Beer (ed.), Constitutionalism in Asia, pp. 122-5; and 'Recent Developments-Constitutional Law,' Law in Japan: An Annual 8 (1975): 205-8.

${ }^{65}$ On the courts and media, see Lawrence W. Beer, 'Freedom of Information and the Evidentiary Use of Film in Japan. . .,' The American Political Science Review 65 (1971): I I 9-34; Genron to masu komi (Hōgaku seminah-Nihon Hyōronsha, I978); Gendai no masu komi, Jurisuto, sōgōtokushū No. 5 (October 1976); Masami I to et al., Broadcasting in Japan (London: Routledge and Kegan Paul, 1978); Horibe Masao, Akusesuken towa nanika (Iwanami Shinsho, 1978). 
endorse political candidates. For example, the press helped to sustain the crisis atmosphere for a time during the 1960 Security Treaty Crisis, they moderated the tension in most cases during the nationwide University Crisis of I968-69, they massively publicized the Lockheed scandals and trials during the 1970 after disclosures were made in the United States, and they have played a major role in activating, publicizing and supporting the consensus against pollution since 1970 . The principal organization for newspapers, television and radio is the Nihon Shinbun Kyōkai (Japan Newspaper Editors and Publishers Association), which at times when a need is felt can form a cohesive power center by alliance among its leaders in the face of external threat. For example, during the Hakata Station Film Controversy of 1969 , the media united to oppose a court order for evidence to be presented (TV film of a student-police confrontation) in the alleged absence of other or better evidence. The Supreme Court upheld the courts' prerogatives after months of well-organized media reistance.

The University of Missouri world survey of press freedom rates Japan highly, but has noted industry centralization and self-regulation as problems. On the latter score, the 'kisha kurabu' (press clubs) attached to politicians or agencies may be mentioned. Reporters from competing papers do not so much compete for news, as they form a coherent group which may determine when what news is suitable for release to their respective papers. Stable ties can develop between a 'reliable source' and a press club; the wishes of both the club and the source may heavily influence what a reporter decides to convey to the public. (Foreign correspondents are not welcome.) There is some merit in the system, because secrecy-loving officials would probably obstruct access to information more substantially, if the cordial relations of mutual trust with the press did not exist. On the other hand, this system of agency-media and reporter-reporter relations too effectively limits the freedom of information, and is one reason why news of such affairs as the Lockheed scandals derived first from foreign sources rather than from Japanese investigative journalism. The right of access to information (akusesuken) and the individual's right to know have been major themes studied by specialists such as Itō Masami, Shimizu Hideo, Okudaira Yasuhiro, and Horibe Masao.

In the Nishiyama Decision of $1978,{ }^{66}$ the Supreme Court made its first ruling on the relationships between state secrets and newsgathering.

${ }^{66}$ Nishiyama v. Japan, Hanrei Jihō 887 (July I I, 1978): 14 4-4I (Sup. Ct., First Petty Bench, May 31, 1978); Ronald G. Brown, 'Government Secrecy and the "People's Right to Know" in Japan: Implications of the Nishiyama Case,' Law in Japan: An Annual 
While attached to the Foreign Ministry, Nishiyama Takichi, a reporter for the Mainichi Shinbun, gained access to secret cables on the negotiation of terms for the reversion of Okinawa to Japan. Nishiyama had received this information from Hasumi Kikuko, a girl friend working in the Ministry. At a Diet committee meeting on March 27, 1972, a Socialist (JSP) member made the contents of the cables, received somehow from Nishiyama, a part of his attack on government policies. The documents contradicted the government's earlier assurances that no secret agreements had been made with the U.S. The Supreme Court held: (I) that the courts have the authority to determine what constitutes a state secret under the National Public Employees Law (and what, for example, is merely a political secret); (2) that the government's secrecy regarding international negotiations in this case was appropriate; (3) that the government's failure to bring the full facts before the Diet did not conflict with the constitutional order or constitute illegal secrecy; and (4) that although free newsgathering and reporting are of special importance to the people's democratic right to know and freedom of expression generally, Nishiyama violated the legal prohibition against inducing divulgence of official secrets by a public employee in his ethically questionable relationship with Hasumi, a married woman.

The right of privacy has been another noteworthy issue in recent law. Expanded press freedom since 1945 has occasioned an increase in journalistic excursions into the private lives of political leaders, other public figures, and ordinary citizens (unknown but for a cruel exposé) ${ }^{67}$ The former have served the people's right to know about and criticize the famous and the powerful. According to a survey, both well-known and unknown victims of defamation and violation of privacy more often suffer in silence and 'go to bed weeping' (nakineiri suru) than assert their legal rights as individuals. The consensus among scholars seems to be that there have been too few legal charges lodged by victims. Where any redress has been sought, the more common solution has been a conciliatory out-of-court settlement with public and private apologies and monetary compensation by publishers.

Io (1977); I 2-39. See also the final report of the Secrecy and Disclosure Subcommittee, Senate Select Committee on Intelligence, October, 1978, U.S. Senate.

${ }^{67}$ Lawrence W. Beer, 'Defamation, Privacy and Freedom of Expression in Japan,' Law in Japan: An Annual 5 (1972): 192-208; Itō Masami, Puraibashii no kenri (Iwanami Shoten, 1963); Shimizu Hideo, Ho to masu komyünikēshon (Shakai Shisōsha, 1970); and Meiyo-puraibashii no shintenkai, furisuto 653 (December I, 1977). On rights of the person in the United States, see Don R. Pember, Privacy and the Press (Seattle: University of Washington Press, 1972); and Arthur R. Miller, The Assault on Privacy (Ann Arbor: University of Michigan Press, 1971). 
Courts and scholars alike have strongly supported the rights to privacy (puraibashii) and good name, but there seems to have been a low demand for the legal protection of these rights at least until the i $970 \mathrm{~s}$. In sharp contrast to official secrecy, the right of privacy seems to have been less honored in group-oriented Japan than the right of families, occupational groups or other groups or communities to know about the affairs of their members, and to impose sanctions for deviance. For example, the institution of ostracism from the community (mura hachibu) for non-conformity is a persistent problem, according to Japan's Civil Liberties Bureau. ${ }^{68}$ On the other hand, if one values the positive aspects of the strong Japanese sense of community, one must hope that a stress on privacy rights will not unduly disturb it.

The constitutional right of privacy was first established in Japan not by a law, but by a 1964 Tokyo district court decision against Mishima Yukio in a case involving his novel Utage no Ato (After the Banquet). ${ }^{69}$ The novel, serialized in Chīo Koron in $196 \mathrm{I}$, dealt in thinly veiled fashion with marital affairs of Arita Hachirō, a Socialist (JSP) politician and unsuccessful gubernatorial candidate in the 1960 Tokyo elections. Arita sued Mishima, who was ordered to pay a substantial amount in damages. The emergence of the right of privacy is an example of the considerable influence of Japanese legal scholars on some areas of the law, the fruitful interaction of campus and court, and the importation of a legal concept from American law into Japanese legal discourse.

${ }^{68}$ Conversation with Onizuka Kentarō, Head, Civil Liberties Bureau, Justice Ministry, October, 1978. See Beer and Weeramantry, 'Human Rights in Japan,' p. I 3 . Mura hachibu, ostracism from the village, was the prototype of this powerful sanction, but for the Tokugawa period, machi hachibu (ostracism from commercial districts of towns and cities) was also common. See Nihon Keizai Jiten (Nihon hyoronsha, 1943), p. I844. Today mura hachibu is the official catch-all term for illegal ostracism. In the cities, mura hachibu may even include ostracism of a housewife in a modern apartment complex by other women living there.

${ }^{69}$ Arita v. Mishima, ${ }_{5}$ Kakyü Minshü (No. 9) 2317 (Tokyo district court, September 28, 1964). For Donald Keen's translation of the novel at issue, see Yukio Mishima, After the Banquet (New York: Alfred A. Knopf, r 963 ). On private enforcement of rights, see Hideo Tanaka and Akio Takeuchi, 'The Role of Private Persons in the Enforcement of Law: A Comparative Study of Japanese and American Law, Law in Japan: An Annual 7 (1974): 34-50. The Civil Code provisions are:

'Article 709. A person who violates intentionally or negligently the right of another is bound to make compensation for damage arising therefrom.

'Article 710 . A person who is liable in compensation for damages in accordance with the provisions of the preceding Article shall make compensation therefor even in respect of a nonpecuniary damage, irrespective of whether such injury was to the person, liberty or reputation of another or to his property rights.'

A theory which would directly apply such constitutional guarantees as good name and privacy without reference to code provisions seems to have little support. See Ukai in Beer, Constitutionalism in Asia, p. 1 22; and Ashibe, Kenpō, pp. 39-97. 
The constitutional basis for the privacy right is found in the sentence, 'All of the people shall be respected as individuals' in Article 13 , while code law provision is detected in Articles 709 and 710 of the Civil Code, under which a person is bound to make compensation for intentional or negligent violation of the right of another, whether 'injury was to the person, liberty, or reputation of another or to his property rights.' Among other noteworthy privacy cases are the following:

( I) A I 969 Supreme Court decision held that, as an aspect of the right of privacy, one has the right not to be photographed against one's will during an illegal demonstration unless the photography was necessary to a criminal investigation. ${ }^{70}$

(2) A I 969 Tokyo high court decision in the Kato Case required a weekly magazine to pay remuneration and to apologize publicly in a national newspaper, on grounds of damage to good name and privacy rights. ${ }^{71}$ The magazine at issue claimed that two famous TV and film personalities cohabited before marriage, which was denied.

(3) In 1970, an injunction to ban the showing of an art film on the grounds of privacy violation was denied. ${ }^{72}$ The film dealt with the early amorous and political affairs of an elderly feminist politician, Kamichika Ichiko; but she herself had publicized her private life on a number of prior occasions, thus negating in the court's view the confidentiality factor necessary for a valid claim of privacy violation.

(4) The 1977 Kawabata Case was settled out of court with public apologies for lack of circumspection. The bereaved family of the late Nobel Prize-winning novelist, Kawabata Yasunari, sued the publisher and author of a novel which suggested that Kawabata's I972 suicide was linked to indiscreet relations with the family maid, apparently an outcast burakumin. ${ }^{\mathbf{7 3}}$

Incidentally, the increase in civil defamation suits in the early 1970 s

${ }^{70}$ Hasegawa v. Japan, 23 Keishī ${ }_{1} 625$ (Sup. Ct., Grand Bench, December 24, 1969). For a translation, see Itoh and Beer, Constitutional Case Law of Japan, pp. I 78-82. Similar specification of the public welfare as what is necessary for criminal justice is used by the same court in Kaneko v. Japan, 23 Keishī $149^{\circ}$ (Sup. Ct., Grand Bench, November 26, 1969 ), translated in ibid., pp. 246-50.

${ }^{71}$ Katō v. Shükan Jitsuwa, Hanrei fihō 537 (1968) 28 (Tokyo district court, November 25, I968), and Shükan Fitsuwa v. Katō, Jurisuto 449 (1970): I 8 (Tokyo high court, December 25, 1969).

72 'Eros + Gyakusatsu' Case, Kamichika v. Art Theatre Guild, Jurisuto 449 (1970): 2 I (Tokyo district court, March I4, 1970), and 23 Köminshü (No. 2) 172 (Tokyo high court, April 13, 1970). See also, Asahi Shinbun, April 13 and 14 (morning and evening edns).

${ }^{73}$ Kawabata v. Chikuma Shobo et al., Tokyo district court, 1977. See Japan Times Weekly Edition, August 27, 1977. Burakumin are still discriminated against socially, despite laws to the contrary, as noted in the concluding section of this paper. 
exemplifies the utility of analyzing the side effects of specific legal changes. ${ }^{74}$ An important but unintended and unforeseen byproduct of legal change in one issue area affected the effects and applications of law in another. Prior to 1970 , very few civil defamation suits had been brought to court compared, for example, to German and French experience under similar defamation laws. ${ }^{75}$ In the early 1970s, the success of groups and individuals bringing civil suits against companies for injury or illness caused by pollution was thoroughly publicized. As a result, popular awareness of the possibility of effective court action against newspapers and other media enterprises for civil defamation rose dramatically, and so did the number of successful suits. ${ }^{76}$.

The obscenity question is another media-related issue affected by the second modern constitutional revolution. Under Article 175 of the Criminal Code, various laws regulating the media, the police laws, obscenity regulation, public security maintenance and thought control were sometimes linked in the Japanese official mind before $1945 .^{77}$ Today, such connections are seen by few officials and citizens. Since the Occupation period, Japan has been again rather tolerant, producing large numbers of erotic books, pictures, magazines, comic books, advertisements, TV broadcasts, motion pictures and tape recordings. ${ }^{78}$

There have been two major Supreme Court decisions on obscenity, both concerning translations of foreign works: the 1957 Lady Chatterley's Lover Case ${ }^{79}$ and the 1969 de Sade Case. ${ }^{80}$ Article 175 provides penalties

\footnotetext{
${ }^{74}$ See the statistics for both civil and criminal defamation in annual reports in Hoso Jihō (Hōōokai).

${ }^{75}$ For example, at least until the I970s, on a per capita basis France and Germany had roughly 200 times as many defamation suits and ten times more convictions than Japan. See K. Igarashi and H. Tamiya, Meiyo to puraibashii (1968), pp. 74-78; Jurisuto 332 (1965): 6o; and Jurisuto 653 (1970).

${ }_{76}$ Conversations with Judge Mutō Shunkō, Legal Training and Research Institute, in July, 1973 and December, 1978. The sharp rise in civil defamation suits peaked in 1973 and thereafter leveled off.

77 The term'waisetsu' (obscenity) and punishment of its 'public display or sale' first appeared in Article 259 of the Criminal Code of 1880 . Article 175 of the 1907 revised Criminal Code remains today the primary legal provision for restraint of obscenity, amended only in 1947 by the addition of imprisonment to fines as possible penalties. See Shimizu, Hō to masu komyūnikēshon, and Okudaira Yasuhiro, Hyögen no jiyū towa nanika (Chūōkōronsha, 1970).

${ }^{78}$ Shimizu, Ho to masu komyünikèshon, pp. I 70-89, presents historical perspective on Japan's obscenity law.

${ }^{79}$ Itō et al. v. Japan, i 1 Keishū (No. 3) 997 (Sup. Ct., Grand Bench, March I 3, 1957); a translation is in Maki, Court and Constitution in Japan, pp. 3-37.

80 Ishii et al. v. Japan, 23 Keishü (No. 1o) I 239 (Sup. Ct., Grand Bench, October I 5, 1969); all opinions are translated in Itoh and Beer, Constitutional Case Law of Japan, pp. $183-217$.
} 
for 'a person who distributes or sells an obscene writing, picture or other object or who publicly displays the same ...81 In Chatterley the Supreme Court held that twelve obscene passages at issue infected D.H. Lawrence's entire work with obscenity, and defined obscenity as follows: ${ }^{82}$ 'In order for a writing to be obscene, it is required that it wantonly arouse and stimulate sexual desire, offend the normal sense of shame, and run counter to proper concepts of sexual morality.'

The Chatterley decision has continued to draw criticism from liberal scholars for arrogating to the courts 'a clinical role' in the event society's moral views become lax. In de Sade, the court generally followed Chatterley doctrine, but seemed to some analysts to stress artistry and intellectual values more than Chatterley in the following passage: ${ }^{83}$

There may be cases where the artistry and intellectual content of a work may diminish and moderate the sexual stimulus caused by its portrayal of sex to a degree less than that which is the object of punishment in the Criminal Code, so as to negate obscenity. ...

Dissenting opinions denied the obscenity of the partial translation of de Sade's In Praise of Vice either because of its artistic and intellectual content, or because its sadistic repulsiveness reduced its erotic appeal to insignificance. Majority doctrine is regarded by commentators as somewhat restrictive. ${ }^{84}$

While providing binding guidelines for official Japan, judicial decisions do not give much hint of the systems for purveying and regulating obscenity in Japan. Critical to freedom of erotica are public agencies and private regulatory agencies connected with different industries. For example, the major motion picture producer-distributors abide by decisions of their own Motion Picture Ethics Committee (Eiga Rinrikitei Kanri Iinkai, or Eirin) in applying the industry's code of ethics and their understanding of what is legally permissible. ${ }^{85}$ The film Kuroi Yuki (Black Snow) was shown with the approval of Eirin, but was held

81 Ministry of Justice, Japan, Criminal Statutes (n.d.), Vol. I, p. 39.

${ }^{82}$ See Maki, Court and Constitution in Japan, p. 7.

${ }^{83}$ Itoh and Beer, Constitutional Case Law of Japan, p. I 84 . See also Chin Kim, 'Constitution and Obscenity: Japan and the U.S.A.,' American Journal of Comparative Law 23 ( 1975 ): 255 .

84 Itō Masami and Shimizu Hideo (eds), Masu komi hōrci yōran (Gendai Jānarizumu Shuppankai, 1966); Shimizu, Ho to masu komyünikēshon; Okudaira, Hyōgen no jïyū towa nanika.

${ }^{85}$ Discussions with Itō Masami, a member of Eirin, August, 1979. Concerning Eirin, see Masu Komi Rinri Kondankai (ed.), Masu komi no shakai sekinin (Nihon Shinbun Kyōkai, 1966), hereafter cited as Sekinin. On Japan's film industry see also J. I. Anderson and D. Richie, The Japanese Film: Art and Industry (New York: Grove Press, 1960). 
obscene by the Tokyo high court in $1969 .{ }^{86}$ For some years after that, the courts did not accept Eirin's view as a basis for immunity from prosecution. Black Snow depicted the life of prostitutes in the environs of an American base. The accused were acquitted on grounds that until this judicial decision, they could assume reasonably that if Eirin approved of a work, it was indeed legal. On the other hand, the Tokyo district court held in the 1978 Nikkatsu Romantic Sex Film Case ${ }^{87}$ that Eirin was an instrument for determining what is in accord with prevailing community standards, and acquitted the Nikkatsu company of obscenity charges based on Eirin approval of its films. However, scores of 'eroductions' appear annually, unregulated by Eirin and rarely restricted by officials.

The Customs Bureau censors imported films and pictures ${ }^{88}$ particularly those brought in for commercial purposes, with the assistance of a committee of citizens of 'learning and experience. ${ }^{89}$ The constitutionality of this system is questioned by scholars, and some judges. In the first test case reaching the appellate level-one involving a challenge to a denial of permission to import nude picture books-the Supreme Court in 1979 ordered a retrial favoring the challenge, but did not clearly present its own doctrine. ${ }^{90}$

Frank and undisguised pornographic writings with the traditional designation of shunpon (literally, springtime books), can be found in specialized shops and do not often generate widespread concern. Weekly pulp magazines, poster advertisements, pornography vending machines, and lewd comic books for children present the most noteworthy problems today. Their content is often strongly erotic and presents a degraded image of humanity, especially women.

About sixty percent of Japan's popular magazine sales take place in newsstands in railway stations, where concession privileges are con-

86 Japan v. Murakami et al., Hanrei Jihō 571 (November I I, I969): I9 (Tokyo high court, September 17, I969).

87 Japan v. Nikkatsu Co., Hanrei Jihō 897 (October I I, 1978): 39-53 (Tokyo district court, June 23, 1978); Asahi Shinbun, June 23 (evening edn), 24, 1978. 'Black Snow' was also a Nikkatsu film. In the I 970 os Nikkatsu turned out a series of sexually explicit films allegedly to help clear up debts due to legal fees in an earlier case, and due to the depression of Japan's film industry. Japan Times, November 4, 1977; Asahi Shinbun, January 28 (evening edn), (evening edn), February 11, May 25, and June 2 I, 1972; and Fujiki Hideo, 'Eirin jiken o meguru hōritsu mondai,' Jurisuto 504 (May 1, 1972): 56. For 'Poruno sangyō toshite no Nihon eiga,' see Asahi Jānaru (April 28, 1972): 38; also Jurisuto, special issue (December ro, 1970).

${ }^{88}$ This was done under the Customs Standards Law (Kanzei teiritsu hō), Law 54 of April II, I9I I, Article I I, which is in Itō and Shimizu, Masu komi hōrei yōran, p. 75.

${ }^{89}$ For examples of seizures at airports, see Asahi Shinbun, January $17,1979$.

90 Hanrei Jihō 707 (1973): 16 (Tokyo high court, April 26, 1973). 
trolled by the private Railroad Benefit Association (Tetsudō Kōsaikai). ${ }^{91}$ The RBA can forbid the sale of a magazine or a particular issue of a magazine which its officials feel might be obscene. Among other sanctions, should police seize a magazine under obscenity law, the RBA may ban the next three issues from all its newsstands.

Local systems for regulating reading material outside train stations vary. For example, the private but powerful Tokyo Newspaper Sellers Commission (Tokyoto Shinbun Sokubai Iinkai) ${ }^{92}$ determines the permissibility of distributing certain magazines to member newsstands and bookstores, and makes periodic spot checks to assure compliance with its policies. If objectionable material is found, a review committee considers the case and may issue a warning. Three warnings in a single year or one police seizure of a magazine may bring suspension of the seller's franchise. In addition, the Publications Ethics Council (Shuppan Rinri Kyogikai) has been the publishing industry's main self-regulatory agency since 1963 ; but it does not appear very vigorous and it is helpless vis-à-vis 'outsiders', who do not belong to the Magazine Publishers Association (Zasshi Kyōkai) or other industry organizations. ${ }^{93}$

The above and other private-sector systems of restraint combine in a complex web; they are supplemented by 39 local youth protection ordinances ${ }^{94}$ Ordinances such as Tokyo's encourage primary reliance upon self-regulatory systems. The Tokyo Governor may give warnings which, if not heeded, are followed by an order to stamp 'unfit for youth' on the cover of offending publications. In some cases, a dozen or more official cautions or warnings have been given before any other enforcement action was taken against pornography affecting children. ${ }^{95}$ In 1979, parental and official concern focused on pornography vending machines within easy access of young children, and on objectionable TV advertisements and films shown during children's usual viewing

\footnotetext{
91 Sekinin, Pp. $5^{1-75}$. (This book, available only at the offices of the Nihon Shinbun Kyōkai, remains a principal source of information on private regulatory systems.) In addition to the criminal and customs law provisions already mentioned, obscenity is also regulated under Kogyō hō (Law 137 of July 10, 1948), Fuzoku eigyō torishimari hō, Kankyō eisei $h \bar{o}$, Denpa $h \bar{o}, H \bar{o} \bar{o} h \bar{o}$, and local youth protection ordinances.

92 Sekinin, Pp. 273, 64 .

${ }^{93}$ Asahi Shinbun, January 22, 1979, an interview with Nunokawa Kakuzaemon, President, Publication Ethics Council, and member, Tokyo Youth Protection Council.

94 Sekinin, p. 208; and Nihon Keizai Shinbun, July 12, 1978.

95 Nihon Keizai Shinbun, July 12, 1978 . For example, amidst widespread parental and public concern, pornography vending machines in Saitama Prefecture increased from 887 in August, I 977 to 2, I I 6 on July 31, I 978 . After a great many warnings, police seized two machines in October, 1978. Asahi Shinbun, October 10, 1978.
} 
hours. ${ }^{96}$ Efforts to solve the latter problem have been led by local TV branches of the Federation of Commercial Broadcasting Labor Unions (Minpō Rōren). ${ }^{97}$

As in other areas of regulation, so in restraining obscenity, particularly on behalf of children, Japanese regulatory authority is spread around among many public and private agencies, while the courts and interested scholars debate rather abstract definitions. The picture that emerges is not one of clear or simple leniency or restrictiveness, but relations between law and society resembling in complexity a kanji ideograph of 25 strokes. As William Spinrad notes in his sociology of civil liberties, formalized and just legal structures are essential to freedom, but are 'never a carbon-copy reflection of the libertarian or anti-libertarian attitudes of politicians or any general public consensus.' 98 This applies to Japan. ${ }^{99}$

Government certification of pre-collegiate textbooks has been another object of controversy for many years, in part in reaction to the very stringent controls of prewar days. In the complicated processes of writing, publishing, local selection, and marketing of such textbooks may be found unintended restrictions on freedom which may be more. important than censorship, ${ }^{100}$ and these problems are further complicated by the polarization of debate on some educational issues along rigid political lines. The textbook certification process takes place within the Ministry of Education. The Ienaga Textbook Review Cases significantly challenged administrative review criteria and processes with respect to textbooks, but also dramatized the continuing sensitivity of many Japanese to anything even faintly reminiscent of the thought control exercised by the prewar government. Professor Ienaga Saburo brought two suits, in 1965 and in 1967 , against the Ministry of Education for requiring him to make changes in the manuscript of his revised high school history text under the Ministry's textbook certification system. Both cases $^{101}$ were on appeal in 1980 , one to the Supreme

\footnotetext{
yo For example, occasionally imported Western films restricted to adult-oriented theatres in the United States are shown on commercial television in Japan. See also Asahi Shinbun, September 22, 23, and December I 2 (evening edn), 1978.

${ }^{9}$ Ibid.

98 Spinrad, Civil Liberties, pp. 5-26, 292-306. On the law and experience of the United States, see The Report of the Commission on Obscenity and Pornography (New York: Bantam Books, 1970), especially Pp. 346-442.

99 For related opinion poll data, see Asahi Shinburn, January 3, 1979, p. 7.

100 See Lawrence W. Beer, 'Education, Politics and Freedom of Expression in Japan: The Ienaga Textbook Review Cases,' Law in Japan: An Annual 8 (1975): 67-9o. 101 Ienaga v. Ministry of Education, Hanrei Jiho 604 (1970): 35 (Tokyo district court, July
} 
Court against a I 975 high court ruling ${ }^{102}$ that the Ministry had failed to adhere to its own criteria in assessing Ienaga's book.

Among the issues raised by the Ienaga cases are freedom of expression, academic freedom, the educational rights of parents, children and the state, and the question of whether the controversies themselves are among the great constitutional cases of modern Japan (a view this writer shares) or exclusively matters of administrative and civil law. A key point of contention was whether Ienaga's book was unfairly critical of the imperial family in discussing the mythological and historical origins of the Emperor system, so as to imply, to some, authoritarian unconcern for the people. The relevant passages are of less interest to Japanese school children than tonight's TV programs; but the length of the Ienaga controversy and the intensity of feeling supporting Ienaga well illustrate the concern of Japanese intellectual élites, if not necessarily the generality of citizens, about possible reversion to reverence for the Emperor and an overturning of the postwar constitutional revolution. The treatment accorded pre- 1945 history, domestic and international, in many school textbooks does gloss over a great many unpleasant facts, and Ienaga is not alone in complaining about this tendency. ${ }^{103}$ Ienaga's special concern is understandable, as he was a principal co-author of the first official history text for the compulsory grades in postwar Japan. ${ }^{104}$ Moreover, official systems for restricting freedom of thought and expression in prewar Japan were realistically seen as coercive measures secondary to and supplementary to the desired natural effects of a modern public education system permeated with the imperial orthodoxy over a period of decades.

\section{Conclusion: Some Problems and Prospects}

Japan is now in a constitutional era when concern about reversion to the prewar system may recede into the background for the salaried man and 17, I 970); and Ienaga v. Ministry of Education, Hanrei fihō, special issue (October I 5, I974) and Jurisulo 569 (1974): 14 (Tokyo district court, July I6, 1974).

${ }^{102}$ Ministry of Education v. Ienaga, Hanrei fiho 800 (1976): i 9 (Tokyo high court, December 20, 1975 ).

${ }^{103}$ Private discussions with Japanese textbook authors at various times during the I970s.

${ }_{104}$ Ministry of Education (ed.), Kuni no ayumi (October, 1946). For a recent expression of Ienaga's views, see Rekishi no naka no kenpō (Tokyo Daigaku Shuppankai, r 977), 2 vols. Ienaga sees the issues in broad constitutional and political terms, as part of efforts on behalf of Article 9 and against constitutional revision. Correspondence with the author, December 10, 1978. 
his family. ${ }^{105}$ Among noteworthy constitutional issues now pending are: the constitutionality of the Self-Defense Forces; limits on the freedom of expression of public employees; delayed justice in the courts; unreviewed internal rules and processes of regulatory agencies which affect individual rights; the extent of expanding environmental rights; discrimination against burakumin (traditional outcasts), women, Okinawans, and resident aliens; and serious malapportionment of seats in the Diet.

In substance, the Supreme Court will most likely concur with the Sapporo high court in upholding the constitutionality of the SelfDefense Forces in the Naganuma Case. ${ }^{106}$ The debate on this case in the past decade has helped to refine and clarify positions on this unique issue. Article 9's pacifist provisions may well continue to be meaningful in law and politics as a unique symbol of self-restraint on military power and the constitutional order under the 'Peace Constitution,' and needs to be understood by Japan's allies. Whether a similar confluence of history, internal law and politics, and geopolitics will enable pacifism to occur in another nation-state remains to be seen.

Discrimination is a significant constitutional and human problem in Japan, although it does not receive much attention from scholars and is of interest to relatively few lawyers, politicians and citizens as yet. The Civil Liberties Bureau works imaginatively to combat discrimination through educational means and the Civil Liberties Commissioner system. ${ }^{107}$ Social discrimination against the million Okinawans is likely to continue. The burakumin, numbering something over I.5 million by government estimates and 3 million according to the Burakumin Liberation Movement, have been helped, as Japanese citizens, by remedial discrimination in the I970s which has provided them with educational and other aid. ${ }^{108}$ However, resident aliens, legal and illegal, have little recourse under Japanese law, and are not eligible for aid from the Civil Liberties Commissioners. ${ }^{109}$ Most notable are roughly $65^{\circ}, 000$ Koreans, 50,000 Chinese, and the 2,500 unwelcome

${ }^{105}$ See Asahi Shinbun, January 1, 1979, pp. 1, 9-13. Survey results therein indicate middle-class preoccupation, not with large political questions, especially those of the past, but with work, inflation, children's education, and other immediate problems.

${ }^{106}$ See sources cited supra, n. 30.

${ }^{107}$ Beer and Weeramantry, 'Human Rights in Japan'.

108 Tokei Nenkan (Okurashō Insatsukyoku, 1977), p. 26.

109 Discussions with Onizuka Kentarō (Head, Civil Liberties Bureau), Nakadaira Kenkichi (attorney), Sasahara Keisuke (attorney), and Andō Isamu (Head, Asian Relations Center, Sophia University, Tokyo), in 1978 and 1979. 
refugees from Indochina in and out of Japan since mid-1975. ${ }^{110}$ For the above and for women, employment discrimination is the most discussed problem. Many burakumin and aliens also suffer private restraints on their choice of a marriage partner. ${ }^{111}$

Revised rules of the LDP for the selection of the party president (and, as a consequence, the Prime Minister) which were used for the first time in late 1978 have established something comparable to a primary election system, though not preliminary, as in the United States, to a popular election for public office, but to a run-off election for party leadership. This may be viewed as a quasi-constitutional innovation, as previously the electors were limited to the parliamentary party, plus prefectural party leaders. Votes were cast by registered LDP members throughout the country in November, 1978, and Ohira Masayoshi received perhaps the highest total (more than 550,000 votes) ever received in an election by a single aspirant to the premiership. ${ }^{12}$ Ohira became party president, when the second-ranking vote-getter (of four candidates), Fukuda Takeo, declined to participate in a run-off election. The new system encourages broader popular participation in LDP politics.

${ }^{110} \mathrm{Japan}$ came under some international pressure in 1978 and 1979 to allow some refugees to reside in Japan. However, as of July 1979, only 12 Southeast Asian refugees had been given visas for a year or so of residence. Of wider interest in Japan with respect to rights of foreigners in Japan was the McLean Case, McLean v. Japan, Hanrei Jihō 903 (December 1, 1978): 3-20 (Sup. Ct., Grand Bench, October 4, 1978). The Supreme Court denied McLean, a teacher active in peaceful and legal activities opposing the American involvement in Vietnam in $1969-1970$, the renewal of his visa, saying that while foreign residents in Japan have the same freedom of expression under the Constitution as Japanese citizens, the Justice Ministry has discretionary authority to take into account whatever factors it thinks appropriate, including legal political activities, when determining whether or not to renew a visa. See Katsuhiko Okazaki, 'Foreign Nationals in Japan and the Human Rights Question,' The Japan Times, December 17, 1978; Kokusaikajidai no hōritsu mondai, furisuto 681 (January 1, 1979), especially pp. 1 3-26, 66-70.

${ }^{11}$ Sources cited supra, n. I09; Asahi Shinbun, January 21, I979; Joyce C. Lebra et al. (eds), Women in Changing Japan (Boulder: Westview Press, 1976); see n. 114, infra.

${ }^{112}$ The LDP rules provide that one electoral point is assigned to a prefectural party chapter for every I, 000 party members. The two national party candidates with the most votes in each prefecture divide the points in proportion to the number of votes each receives in the 'primary'. No other candidates are allotted electoral points. The voting for the four candidates in the 1978 primary election was as follows: Ohira Masayoshi 550,891 (748 points); Fukuda Takeo, 472,503 (638); Nakasone Yasuhiro, 197,957 (93); Komoto Toshio, 88,9 77 (46). Asahi Shinbun, morning and evening edns, November 27, 28, and December 8,1978 . After the first round in a primary with more than two candidates in which no one has received a majority of the points, the top two vote-getters compete in a run-off election. In 1978 , Fukuda withdrew his candidacy before the run-off. See also Minoru Shimizu, 'LDP Reform Movement Retrogresses,' The Japan Times, May 24, 1979. 
However, the malapportionment of seats in the House of Representatives and the less-powerful House of Councilors under the Public Office Election Law is an unresolved constitutional problem the political parties have chosen not to solve by legislative action. In 1976 , the Supreme Court held unconstitutional the distribution of lower house seats in $1972 .{ }^{113}$ The degree of malapportionment was against requirements for equality under the law and universal adult suffrage, and against the prohibition on discrimination against any particular candidates for public office. ${ }^{114}$ (Candidates, for example, who must get twice as many votes as candidates in another district in order to be elected are suffering a form of discrimination.) But the court invalidated neither the election nor the subsequent actions of the malapportioned Diet, as requested by the plaintiffs. In 1975 the Diet added twenty seats, bringing the total to $5 \mathrm{I} I i^{115}$ but the apportionment as of the December 1976 general elections were also challenged, in two cases decided in 1978. The first decision, handed down by the Tokyo high court, ${ }^{116}$ upheld the constitutionality of the apportionment; while the second, much more widely supported, ${ }^{117}$ struck it down as a violation of the Article 14 requirement of equality under the law. Both holdings were on appeal to the Supreme Court before October, 1979, when the next lower

${ }^{113}$ Kuroka v. Chiba Prefecture Election Commission, 30 Minshū 223 (Sup. Ct., Grand Bench, April 14, 1976). See 'Recent Developments,' Law in Japan: An Annual 9 (1976): I 5 I-2.

114 Constitution of Japan:

'Article 14. All of the people are equal under the law and there shall be no discrimination in political, economic or social relations because of race, creed, sex, social status or family origin. ...'

'Article 15 . The people have the inalienable right to choose their public officials and to dismiss them.

'2. All public officials are servants of the whole community and not of any group thereof.

'3. Universal adult suffrage is guaranteed with regard to the election of public officials.

'4. In all elections, secrecy of the ballot shall not be violated. A voter shall not be answerable, publicly or privately for the choice he has made.'

'Article 44. The qualifications of members of both Houses and their electors shall be fixed by law. However, there shall be no discrimination because of race, creed, sex, social status, family origin, education, property or income.' Itoh and Beer, Constitutional Case Law of Japan, pp. 258-9, 261.

${ }^{115}$ Law 63 of 1975 added twenty seats to the House of Representatives, and created new election districts in Tokyo, Chiba, Saitama, and Kanagawa, areas severely afflicted with malapportionment.

${ }^{116}$ Hanrei Jihō 902 (November 21, 1978): 24-34 (Tokyo high court, September I I, 1978 ).

117 Koshiyama v. Election Commission, Hanrei fihō 902 (November 21 , 1978): 34-51 (Tokyo high court, September I3, 1978). 
house election was held. ${ }^{118}$ The apportionment as of the 1979 elections was challenged, and the apportionment as of the subsequent June 22, 1980 elections is also expected to be challenged. Some LDP leaders have expressed their disagreement with the 'one man-one vote' thinking behind the 1976 and 1978 judgments of unconstitutionality and the repeated challenges; but opposition politicians also see a threat to their political positions in change. ${ }^{119}$ In September 1978 , the apportionment caused discrepancies in the effective weight of a vote, depending on election district, ranging up to 3.74 to $\mathrm{I}$ in the lower house and $5.3 \mathrm{I}$ to $\mathrm{I}$ in the upper house, with I representing the minimum weight. ${ }^{120}$ The interplay of the Supreme Court and the Diet on the malapportionment issue will merit close attention in the I 980 s.

In addition, a November I979 district court decision raised the spectre of Japan's imperial past in sentencing two radicals to death for killing eight and injuring close to 200 people in a series of bombings between 1972 and 1975, and for plotting the assassination of the Emperor. Although neither law nor constitution recognizes any difference between attempted murder of the Emperor and of an ordinary citizen, the presiding judge raised political hackles by suggesting, to many, a basic difference in holding the conspirators 'had a firm intent to assassinate the Emperor, the symbol of the unity of the people of Japan, with bombs.' 121

On balance, however, despite political and judicial problems, the second modern constitutional revolution of Japan is likely to be guarded with vigilance by substantial forces in the public and private sectors. In Bonn, Matsuyama Yukio, international journalist with the Asahi Shinbun, put well the hopes of many Japanese: ${ }^{122}$

We want to be peaceful, and we want to remind you that Japan is next to none in her love of freedom, after having enjoyed its sweetness in these recent years. -And we will not have it taken away by any government of any form. I still remember being deeply impressed with President Kennedy's remarks on his visit to the Berlin Wall, when he said, 'Ich bin ein Berliner.' He meant, of course,

${ }_{11}$ Asahi Shinbun, September 7, 12, 1 3, 14, 17, and October 30, 1978.

119 Asahi Shinbun, September 27, 1978.

120 Sources cited supra, n. I 8.

121 Tokyo district court, November 13, I979; Asahi Shinbun, November 13 (evening edn) and 14, 1979; The Japan Times, November 16, 1979. On the face of it, the judge was merely stating a fact and quoting the constitution, but the fact that it was made into an incident is another example of the supersensitivity, among many opposition politicians and opinion purveyors, of the issue of the Emperor.

${ }^{122}$ Yukio Matsuyama, 'What Has Been Changing in Japanese Politics and What Not?,' unpublished speech, Trilateral Commission, Bonn, West Germany, October 23, 1977, pp. 9-10. 
that he was a free man, dedicated to liberty. And I still remember being deeply impressed by Martin Luther King, when he raised a vision for all mankind and said, 'I have a dream.' For man to be free and at peace with his neighbors. I have a dream that the day will come when I shall be able to say to the world at large, 'Ich bin ein Japaner.' And the world will know that such is a man who tries to keep his liberty through peaceful means.

I share those hopes for Japan, and believe that constitutional democracy will probably continue without further constitutional revolution, barring a severe economic dislocation, the resurgence of extreme nationalism, or a holocaust. The reasons for optimism in 1980 are that competing constitutional structures and some values of Japanese law and society give substance to such hopes, and that the balance of political forces for and against stable Japanese-style democracy seems more likely to weigh increasingly on the side of responsible freedom. 


\title{
Occasional Papers/Reprints Series in Contemporary Asian Studies
}

\author{
500 West Baltimore Street \\ Baltimore, MD. 21201 \\ U.S.A. \\ (301) 528-3870 \\ 1977 Series
}

No. 1 - 1977

ISSN 0730-0107

ISBN 0-942182-00-6

Chinese Attitude Toward Continental Shelf and Its Implication on Delimiting Seabed in Southeast Asia (Hungdah Chiu) 32 pp.

$\$ 1.00$

No. 2 - 1977

ISSN 0730-0107

ISBN 0-942182-01-4

Income Distribution in the Process of Economic Growth of the Republic of China (Yuan-Li Wu) 45 pp.

No. 3 - 1977

ISSN $0730-0107$

ISBN 0-942182-02-2

The Indonesian Maoists: Doctrines and Perspectives (Justus M. van der Kroef) 31 pp.

No. 4 - 1977

ISSN 0730-0107

ISBN 0-942182-03-0

Taiwan's Foreign Policy in the 1970s: A Case Study Adaptation and

Viability (Thomas J. Bellows) 22 pp.

No. 5 - 1977

ISSN 0730-0107

ISBN 0-942182-04-9

Asian Political Scientists in North America: Professional and Ethnic Problems (Edited by Chun-tu Hsueh) 148 pp. Index

No. 6 - 1977

ISSN 0730-0107

ISBN 0-942182-05-7

The Sino-Japanese Fisheries Agreement of 1975: A Comparison with Other North Pacific Fisheries Agreements (Song Yook Hong) 80 pp.

No. 7 - 1977

ISSN 0730-0107

ISBN 0-942182-06-5

Foreign Trade Contracts Between West German Companies and the People's Republic of China: A Case Study (Robert Heuser) 22 pp. 
Reflections on Crime and Punishment in China, with Appended Sentencing Documents (Randle Edwards, Translation of Documents by Randle Edwards and Hungdah Chiu) 67 pp.

No. 9 - 1977

ISSN 0730-0107

ISBN 0-942182-08-1

Chinese Arts and Literature: A Survey of Recent Trends (Edited by Wai-lim Yip) 126 pp.

No. 10 - 1977

ISSN 0730-0107

ISBN 0-942182-09-X

Legal Aspects of U.S.-Republic of China Trade and Investment - Proceedings of a Regional Conference of the American Society of International Law (Edited by Hungdah Chiu and David Simon) 217 pp. Index

No. 11 - 1977

ISSN 0730-0107

ISBN 0-942182-10-3

Asian American Assembly Position Paper: I. A Review of U.S. China Relations 62 pp.

No. 12 - 1977

ISSN 0730-0107

ISBN 0-942182-11-1

Asian American Assembly Position Paper: II. A Review of U.S. Employment Policy $24 \mathrm{pp}$.

1978 Series

No. 1 - 1978 (13)

ISSN 0730-0107

ISBN 0-942182-12-X

Indian Ocean Politics: An Asian-African Perspective (K.P. Misra) 31 pp.

No. 2 - 1978 (14)

ISSN 0730-0107

ISBN 0-942182-13-8

Normalizing Relations with the People's Republic of China: Problems, Analysis, and Documents (Edited by Hungdah Chiu, with contribution by G. J. Sigur, Robert A. Scalapino, King C. Chen, Eugene A. Theroux, Michael Y.M. Kau, James C. Hsiung and James W. Morley) 207 Pp. Index

No. 3 - 1978 (15)

ISSN 0730-0107

ISBN 0-942182-14-6

Growth, Distribution, and Social Change: Essays on the Economy of the Republic of China (Edited by Yuan-li Wu and Kung-chia Yeh) 227 pp. Index

No. 4 - 1978 (16)

ISSN 0730-0107

ISBN 0-942182-15-4

The Societal Objectives of Wealth, Growth, Stability, and Equity in Taiwan (Jan S. Prybyla) 31 pp. 
No. 5 - 1978 (17)

ISSN 0730-0107

ISBN 0-942182-16-2

The Role of Law in the People's Republic of China as Reflecting Mao Tse-Tung's Influence (Shao-Chuan Leng) $18 \mathrm{pp}$.

No. 6 - 1978 (18)

ISSN 0730-0107

ISBN 0-942182-17-0

Criminal Punishment in Mainland China: A Study of Some Yunnan Province Documents (Hungdah Chiu) 35 pp.

$\$ 1.00$

No. 7 - 1978 (19)

ISSN 0730-0107

ISBN 0-942182-18-9

A Guide to the Study of Japanese Law (Lawrence W. Beer and Hidenori Tomatsu) $45 \mathrm{pp}$.

No. 8 - 1978 (20)

ISSN 0730-0107

ISBN 0-942182-19-7

The Pueblo, EC-121, and Mayaguez Incidents: Some Continuities and Changes (Robert Simmons) 40 pp.

$\$ 2.00$

No. 9 - 1978 (21)

ISSN 0730-0107

ISBN 0-942182-20-0

Two Korea's Unification Policy and Strategy (Yong Soon Yim) 82 pp. Index

\section{Series}

No. 1 - 1979 (22)

ISSN 0730-0107

ISBN 0-942182-21-9

Asian Immigrants and Their Status in the U.S. (Edited by Hungdah Chiu) 54 pp.

$\$ 2.00$

No. 2 - 1979 (23)

ISSN 0730-0107

ISBN 0-942182-22-7

Social Disorder in Peking After the 1976 Earthquake Revealed by a Chinese Legal Documents (Hungdah Chiu) 20 pp.

No. 3 - 1979 (24)

ISSN 0730-0107

ISBN 0-942182-23-5

The Dragon and the Eagle - A Study of U.S.-People's Republic of China Relations in Civil Air Transport (Jack C. Young) 65 pp. $\quad \$ 3.00$

No. 4 - 1979 (25)

ISSN $0730-0107$

ISBN 0-942182-24-3

Chinese Women Writers Today (Edited by Wai-lim Yip and William Tay) $108 \mathrm{pp}$.

No. 5 - 1979 (26)

ISSN 0730-0107

ISBN 0-942182-25-1

Certain Legal Aspects of Recognizing the People's Republic of China (Hungdah Chiu) 49 pp.

No. 6 - 1979 (27)

ISSN 0730-0107

ISBN 0-942182-26-X

China's Nationalization of Foreign Firms: The Politics of Hostage Capitalism, 1949-1957 (Thomas N. Thompson) 80 pp. Index 
U.S. Status of Force Agreement with Asian Countries: Selected Studies (Charles Cochran and Hungdah Chiu) 130 pp. Index

No. 8 - 1979 (29)

ISSN 0730-0107

ISBN 0-942182-28-6

China's Foreign Aid in 1978 (John F. Copper) 45 pp.

$\$ 2.00$

\section{Series}

No. 1 - 1980 (30)

ISSN 0730-0107

ISBN 0-942182-29-4

The Chinese Connection and Normalization (Edited by Hungdah Chiu and Karen Murphy) 200 pp. Index

$\$ 5.00$

No. 2 - 1980 (31)

ISSN $0730-0107$

ISBN 0-942182-30-8

The Conceptual Foundations of U.S. China Policy: A Critical Review (James C. Hsiung) 17 pp.

$\$ 1.00$

No. 3 - 1980 (32)

ISSN 0730-0107

ISBN 0-942182-31-6

Policy, Proliferation and the Nuclear Proliferation Treaty: U.S. Strategies and South Asian Prospects (Joanne Finegan) 61 pp.

No. 4 - 1980 (33)

ISSN $0730-0107$

ISBN 0-942182-32-4

A Comparative Study of Judicial Review Under Nationalist Chinese and American Constitutional Law (Jyh-pin Fa) 200 pp. Index

$\$ 3.50$

No. 5 - 1980 (34)

ISSN 0730-0107

ISBN 0-942182-33-2

Certain Problems in Recent Law Reform in the People's Republic of China (Hungdah Chiu) 34 pp.

No. 6 - 1980 (35)

ISSN 0730-0107

ISBN 0-942182-340

China's New Criminal \& Criminal Procedure Codes (Hungdah Chiu) 16 pp.

$\$ 1.00$

No. 7 - 1980 (36)

ISSN 0730-0107

ISBN 0-942182-35-9

China's Foreign Relations: Selected Studies (Edited by F. Gilbert Chan \& Ka-che Yip) 115 pp.

$\$ 3.00$

No. 8 - 1980 (37)

ISSN $0730-0107$

ISBN 0-942182-36-7

Annual Review of Selected Books on Contemporary Asian Studies (1979-1980) (Edited by John F. Copper) 45 pp. 
1981 Series

No. 1 - 1981 (38)

ISSN 0730-0107

ISBN 0-942182-37-5

Structural Changes in the Organization and Operation of China's Criminal Justice System (Hungdah Chiu) 31 pp.

No. 2 - 1981 (39)

ISSN 0730-0107

ISBN 0-942182-38-3

Readjustment and Reform in the Chinese Economy (Jan S. Prybyla) 58 pp.

No. 3 - 1981 (40)

ISSN 0730-0107

ISBN 0-942182-39-1

Symposium on the Trial of Gang of Four and Its Implication in China (Edited by James C. Hsiung) 118 pp.

No. 4 - 1981 (41)

ISSN 0730-0107

ISBN 0-942182-40-5

China and the Law of the Sea Conference (Hungdah Chiu) 30 pp. $\quad \$ 2.00$

No. 5 - 1981 (42)

ISSN 0730-0107

ISBN 0-942182-41-3

China's Foreign Aid in 1979-80 (John Franklin Copper) 54 pp.

$\$ 2.00$

No. 6 - 1981 (43)

ISSN 0730-0107

ISBN 0-942182-42-1

Chinese Regionalism: Yesterday and Today (Franz Michael) 35 pp. $\quad \$ 2.00$

No. 7 - 1981 (44)

ISSN $0730-0107$

ISBN 0-942182-43-X

Elite Conflict in the Post-Mao China (Parris H. Chang) 30 pp.

$\$ 2.00$

No. 8 - 1981 (45)

ISSN 0730-0107

ISBN 0-942182-44-8

Proceedings of Conference on Multi-system Nations and International Law: International Status of Germany, Korea, and China (Edited by Hungdah Chiu and Robert Downen) 203 pp. Index

\section{Series}

No. 1 - 1982 (46)

ISSN 0730-0107

ISBN 0-942182-45-6

Socialist Legalism: Reform and Continuity in Post-Mao People's Republic of China (Hungdah Chiu) 35 pp.

No. 2 - 1982 (47)

ISSN 0730-0107

ISBN 0-942182-46-4

Kampuchea, The Endless Tug of War (Justus M. Van der Kroef) 51 pp.

No. 3 - 1982 (48)

ISSN $0730-0107$

ISBN 0-942182-47-2

Social Change on Mainland China and Taiwan, 1949-1980 (Alan P.L. Liu) 55 pp. 
No. 4 - 1982 (49)

Taiwan's Security and United States Policy: Executive and Congressional Strategies in 1978-1979 (Michael S. Frost) $39 \mathrm{pp}$.

$\$ 2.50$

No. 5 - 1982 (50)

ISSN 0730-0107

ISBN 0-942182-49-9

Constitutional Revolution in Japanese Law, Society and Politics (Lawrence $W$. Beer) $35 \mathrm{pp}$. 


\section{ORDER FORM}

To Occasional Papers/Reprints Series in Contemporary Asian Studies, University of Maryland School of Law, 500 West Baltimore Street, Baltimore, Maryland 21201, U.S.A.

Check One:

Please Send:

No.

Author

Title

Copies

Please start my subscription of the OPRSCAS:

Starting issue

Subscription price is U.S. $\$ 10.00$ for 8 issues (regardless of the price of individual issues in the U.S. and Canada and $\$ 12.00$ for overseas.)

My check of U.S. $\$$ is enclosed $\operatorname{copy}(s)$ of invoice/receipt required. (Institution/library may request billing before making payment) (Make check payable to OPRSCAS)

Please send book to:

Name/Corp./Library:

Address: (Please include zip code) 
